\title{
Five New Species of Moelleriella With Aschersonia-like Anamorphs Infecting Scale Insects (Coccidae) in Thailand
}

\author{
Artit Khonsanit \\ National Center for Genetic Engineering and Biotechnology \\ Wasana Noisripoom \\ National Center for Genetic Engineering and Biotechnology \\ Suchada Mongkolsamrit \\ National Center for Genetic Engineering and Biotechnology \\ Natnapha Phosrithong \\ National Center for Genetic Engineering and Biotechnology \\ Janet Jennifer Luangsa-ard ( $\sim$ jajen@biotec.or.th ) \\ National Center for Genetic Engineering and Biotechnology https://orcid.org/0000-0001-6801-2145
}

\section{Research Article}

Keywords: Clavicipitaceae, Entomopathogenic fungi, Hypocreales, Phylogeny, Taxonomy

Posted Date: February 25th, 2021

DOI: https://doi.org/10.21203/rs.3.rs-254595/v1

License: (9) (1) This work is licensed under a Creative Commons Attribution 4.0 International License. Read Full License 


\section{Abstract}

The genus Moelleriella and its aschersonia-like anamorph mostly occur on scale insects and whiteflies. It is characterized by producing brightly colored stromata, obpyriform to subglobose perithecia, cylindrical asci, disarticulating ascospores inside the ascus and fusiform conidia, predominantly found in tropical and occasionally subtropical regions. From our surveys and collections of entomopathogenic fungi, scale insects and whiteflies pathogens were found. Investigations of morphological characters and multi-locus phylogenetic analyses based on partial sequences of LSU, TEF and RPB1 were made. Five new species of Moelleriella and their aschersonia-like anamorphs are described here, including $M$.

chiangmaiensis, M. flava, M. kanchanaburiensis, M. nanensis and M. nivea. They were found on scale insects, mostly with flat to thin, umbonate, whitish stromata. Their anamorphic and telemorphic states were mostly found on the same stroma, possessing obpyriform perithecia, cylindrical asci with disarticulating ascospores. Their conidiomata are widely open with several locules per stroma, containing cylindrical phialides and fusiform conidia. However, some specimens of $M$. chiangmaiensis produce hat-shaped stromata apart from the commonly found umbonate stromata, while $M$. flava had yellow stromata with one conidioma per stroma, and M. kanchanaburiensis was found only in its anamorphic state.

Furthermore, the perithecia of $M$. nanensis were completely embedded in stromata as opposed to other species with semiimmersed perithecia. We also found a teleomorph link to $M$. sinensis, an anamorphic species reported from southeastern China.

\section{Introduction}

The entomopathogenic genus Moelleriella Bres. (Clavicipitaceae, Hypocreales, Ascomycota) was separated from allied genera of Aschersonia Montagne, Conoideocrella D. Johnson, G.H. Sung, Hywel-Jones \& Spatafora, Helicocollum Luangsaard, Mongkolsamrit, Noisripoom \& Thanakitpipattana, Orbiocrella D. Johnson, G.H. Sung, Hywel-Jones \& Spatafora, Regiocrella P. Chaverri \& K.T. Hodge and Samuelsia P. Chaverri \& K.T. Hodge (Montagne 1848, Chaverri et al. 2005a, Chaverri et al. 2008; Johnson et al. 2009; Luangsa-ard et al. 2017). Moelleriella and Samuelsia produce aschersonia-like anamorphs (Chaverri et al. 2008; Tadych et al. 2009; Mongkolsamrit et al. 2015. oelleriella species can be recognized with teleomorphs having ascospores disarticulating into part-spores (Chaverri et al. 2008; Mongkolsamrit et al. 2015), whereas Samuelsia produce filiform with multiseptate ascospores. The anamorph in Moelleriella produce fusiform conidia while in Samuelsia only small allantoid conidia are found (Chaverri et al. 2008; Tadych et al. 2009; Mongkolsamrit et al. 2011a, b). Species found in teleomorphs state of Aschersonia (Hypocrella) producing whole ascospores, apart from its conidial state (Montagne 1848; Saccardo 1878; Petch 1921; Hywel-Jones and Evans 1993; Hywel-Jones and Samuels 1998; Chaverri et al. 2008; Mongkolsamrit et al. 2009, 2015).

The genus Moelleriella is recognized by the brightly colored stromata on scale insects (Coccidae, Lecaniidae) and whiteflies (Aleyrodidae) (Chaverri et al. 2008; Tadych et al. 2009; Mongkolsamrit et al. 2011b, 2015). Its species were commonly found in tropical and occasionally in subtropical regions (Montagne 1848; Petch 1921, 1925, 1931; Mains 1959a, 1959b; Hywel-Jones and Evans 1993; Hywel-Jones and Samuels 1998; Chaverri et al. 2008; Tadych et al. 2009; Qiu et al. 2009, 2010; Mongkolsamrit et al. 2011a, 2011b, 2015) as biotrophic parasites of plants (Tadych et al. 2009). In Thailand, nine known species were reported, including M. alba, M. chumphonensis, M. javanica, M. phukhiaoensis, M.pongdueatensis, M.raciborskii, M.reineckeana, M. schizostachyi and M.thanathonensis (Hywel-Jones and Samuels 1998; Luangsa-ard et al. 2008, 2012; Mongkolsamrit et al. 2010, 2015, Li et al. 2016, Tibpromma et al. 2017).

From our surveys of entomopathogenic fungi on scale insects and whiteflies in Thailand specimens were mostly found on the underside of leaves (abaxial surface), occasionally found on its upper side (adaxial surface). Eighteen strains of Thai Moelleriella species were studied to clarify the relationships of these collections by using morphological characters and multi-locus phylogenetic analyses to known members of Clavicipitaceae and describe the new taxa to accommodate species diversity in Moelleriella. 


\section{Materials And Methods}

\section{Collectionsand isolation}

Moelleriella specimens attached to the upper side and underside of leaves were collected from national parks, wildlife sanctuaryin Thailand throughout the year from 2005-2014. The specimens were separated and placed in plastic boxes $(3 \times 6 \mathrm{~cm}$ or $6 \times 10 \mathrm{~cm})$ before returning to the laboratory for isolation. Fresh materials were examined and isolated in pure cultures from both the teleomorph and anamorph following the techniques described by Mongkolsamrit et al. (2009).

\section{Morphological observations}

For morphological observations, the samples were photographed in the field by using a digital Nikon D5100 camera, or in the laboratory using an Olympus DP70 Digital Camera installed on an Olympus SZX12 stereo microscope. Pure cultures on PDA were photographed using a digital Nikon D5100 camera. The Sixth Royal Horticultural Society (R.H.S.) color chart was used to characterize the colors of fresh specimens and cultures. To observe internal characteristics of the stromata, such as conidiomata and perithecia, sections were made using a cryostat rotary microtome (SLEE.MEV). The micromorphological characteristics such as phialides, paraphyses, conidia, asci, asci caps and part-spores were mounted with lactophenol or lactophenol cotton blue solution and observed using an Olympus $\mathrm{CH} 40$ compound microscope for measurements, measuring the size with a minimum sampling size 5-10 (for conidiomata and perithecia) to 50-100 (for phialides, conidia, asci, asci caps and part-spores), and the average size was calculated to mean \pm standard deviation values.Photographs of the micro-morphological characters were done using a DP70 digital camera installed on an Olympus BX51 compound microscope.

\section{DNA extraction, PCR amplification and sequencing}

Total DNA was extracted from mycelial mass harvested on PDA using a modified cetyltrimethyl-ammonium bromide (CTAB) method as previously described in Khonsanit et al. (2020). Four nuclear loci, including the nuclear ribosomal internal transcribed spacer (ITS),

the large subunit of the ribosomal DNA (LSU), translation elongation factor-1a gene (TEF) and the partial regions of the RNA polymerase II largest (RPB1), were sequenced. The primer pairs and thermocycler conditions for PCR amplifications used in this study followed the protocol described in Mongkolsamrit et al. (2018). The purified PCR products were sequenced with PCR amplification primers for Sanger dideoxy sequencing.

\section{Phylogenetic analyses}

The generated DNA sequences in this study were checked for ambiguous bases using BioEdit (Hall 2013) and then submitted to GenBank. Sequences of ITS, LSU, TEF and RPB1 of other taxa for the analyses were taken from previous studies as shown in Table 1. ITS sequences were considered only for barcoding purposes and not included in the multigene analyses. The phylogenetic analyses were performed using Maximum likelihood (ML) and Bayesian inference (BI). The ML analysis was performed with RAxML v. 8.2.12 (Stamatakis 2014) using GTR-GAMMA model of evolution with 1000 bootstrap replicates. The BI analysis was performed using MrBayes v.3.2.7a (Ronquist et al. 2012) with GTR model. Four Markov chains were run from random starting trees for five million generations using sampled frequency of 100 generations and a burn-in of $10 \%$ from the total run. RAXML and BI were run on XSEDE in CIPRES portal (www.phylo.org). Phylogenetic trees were visualized in TreeView v.1.6.6 (Page 1996).

\section{Results}

\section{Phylogenetic analyses}


The strains of Moelleriella (18 strains for LSU, 17 strains for TEF and 15 strains from RPB1) were included in the phylogenetic analyses. A phylogenetic tree using a combined dataset of seventy specimens including allied genera, such as Aschersonia, Conoideocrella, Helicocollum, Orbiocrella, Regiocrella and Samuelsia with Purpureocillium lilacinum (CBS 431.87), P. lilacinum (CBS 284.36) as outgroup is shown in Fig. 1.

The numbers on the branches represent bootstrap values from the RAxML analysis and posterior probability from the Bayesian inference. The results revealed that seven major clades representing various genera found in Clavicipitaceae, such as Aschersonia, Conoideocrella, Helicocollum, Moelleriella, Orbiocrella, Regiocrella and Samuelsia are independently formed. The Moelleriella clade segregated into two distinct clades, Clade A and Clade B. Clade A segregated in two sister clades, subclade I and subclade II. Clade A subclade I includes five new species, namely M. chiangmaiensis, M. flava, M.Kanchanaburiensis, M. nanensis and M.nivea, and seven known species, viz. M. gracilispora, M. mollii, M. ochracea, M. phukhiaoensis, M. pongdueatensis, M. sinensis and M. zhongdongii. Most of the species in subclade I were from the Old World (OW), except M. ochracea and M. zhongdongii that were found from the New World (NW). Clade A subclade I species have mostly flattened stromata, except for M. pongdueatensis and $M$. zhongdongii with stud-shaped and thick-pulvinate stromata, respectively. Most species in subclade I have whitish stromata, except M.flava, M. phukhiaoensis and M.pongdueatensis which have pale yellow to yellow stromata. Subclade II includes ten known species, seven of which were found in the NW, namely M. basicystis, M. disjuncta, M. evansii, M. libera, M. phyllogena, M. rhombispora and $M$. umbospora. Only three were found from the OW, such as M. alba, M. chumphonensis and M. raciborskii. Five species in subclade II produce perithecia in tubercles, viz. M. alba, M. chumphonensis, M. evansii, M. libera and M. raciborskii, while other species have semi-immersed to immersed perithecia in stromata, such as M.basicystis, M. disjuncta, M.phyllogena, M. rhombispora and M.umbospora. Furthermore, most of the species in this subclade II have pale yellow to yellow stromata, except for M.alba with whitish stromata. Clade B includes nine known species with fully embedded perithecia, the species in this clade can be found both in the OW (M. africana, $M$. insperata, $M$. reineckiana, $M$. schizostachyi) and the NW (M. boliviensis, M. epiphylla, M. macrostroma, M. sloaneae, M. turbinata). Additionally, the phylogenetic analyses of our study revealed that the species in each clade show no correlation to the different geographic areas.

\section{Taxonomy}

Moelleriella chiangmaiensis Khonsanit, Noisripoom, Phosrithong \& Luangsa-ard, sp. nov. Fig. 2

\section{MycoBank. MB835903}

Anamorph. Aschersonia-like.

Etymology. Refers to the locality where the type specimen was found, Chiang Mai Province.

Typification. THAILAND. Chiang Mai Province, Doi Inthanon National Park, KM. 25 Nature Trail; 18³5'15.66"N, 98 29'11.69"E; on scale insect (Coccidae) found on the underside of dicotyledonous leaves; 30 Jun. 2005; B. Thongnuch, K. Tasanathai, N. Boonyuen, P. Srikitikulchai, R. Ridkaew, S. Mongkolsamrit, W. Chaygate (holotype BBH13024, ex-type living culture BCC18029)

Description.Anamorphic stromata convex, flattened, globose to subglobose, hat-shaped, raised, 1-7 mm in diam, white, pale greenish yellow (160C) to moderate yellow (160A) conidial masses. Conidiomata scattered, irregularly in shaped, widely open orifice, rim around the orifice thick and raised, 400-500 × 150-270 $\mu \mathrm{m}$. Phialides hyaline, cylindrical, (8-)9.5-15(-20) × 1$2 \mu \mathrm{m}$. Conidia hyaline, (7-)8-10(-11) × 1.5-2 $\mu \mathrm{m}$. Paraphyses present, hyaline, filiform, up to $130 \mu \mathrm{m}$ long, 1-1.5 $\mu \mathrm{m}$ wide. Teleomorphic stromata thin-umbonate, raised, with globose to subglobose base, 4-7 mm diam, white to moderate yellow (162A). Perithecia semi-embedded in stromata, most perithecia fused together, occasionally developing singly in stromata, numerous perithecia per stroma ( $\leq 10)$, obpyriform, 450-500 × 260-360 $\mu \mathrm{m}$. Ostioles deep orange yellow (163A). Asci hyaline, cylindrical, (102-)120-167(-220) × (4-)4.5-6.5(-7) $\mu \mathrm{m}$. Asci caps convex, $2 \times 4 \mu \mathrm{m}$. Ascospores hyaline, 
disarticulating into part-spores, cylindrical with rounded ends, (7-)9-11(-12) × 1-2 $\mu \mathrm{m}$. The teleomorph and anamorph could be present in the same stroma.

Culture characteristics. Colonies on PDA forming a compact mycelium, convex to pulvinate, attaining a diam of 8-10 mm in $2 \mathrm{wk}$, white, pale yellow green (155A) conidial masses covering stromatic colonies. Colony reverse brownish orange (164A), pale yellow (164D) at the margins.

Habitat. On scale insects (Coccidae) found on the underside of dicotyledonous leaves.

Additional specimens examined. THAILAND, Chiang Mai Province, Doi Inthanon National Park, KM. 25 Nature Trail; $18^{\circ} 35^{\prime} 15.66^{\prime \prime} \mathrm{N}, 98^{\circ} 29^{\prime} 11.69^{\prime \prime} \mathrm{E}$; on scale insects (Coccidae) found on the underside of dicotyledonous leaves; 30 Jun. 2005 ; B. Thongnuch, K. Tasanathai, N. Boonyuen, P. Srikitikulchai, R. Ridkaew, S. Mongkolsamrit, W. Chaygate (BBH13024, BCC18030, BCC18031, BCC18064); Krabi Province, Jiranan Techaprasan's house (Thap Prik); 8¹0'53.31"N, 9852'38.66"E; on scale insects (Coccidae), found on the underside of plant leaves (Poaceae); 12 Dec. 2012; J. Techaprasan (BBH33051); on scale insect (Coccidae) found on the underside of dicotyledonous leaves; 1 Jan. 2013; J. Techaprasan (BBH33697); Nakhon Ratchasima Province, Khao Yai National Park, Pha Kluaimai Waterfall Nature Trail; 14²6'21.46"N, 101²2'20.20"E; on scale insects (Coccidae) found on the underside of dicotyledonous leaves; 10 Jan. 2013; D. Thanakitpipattana, K. Tasanathai, P. Srikitikulchai (BBH33709, BCC60941)

Notes. Phylogenetically, M. chiangmaiensis is closely related to M. nanensis, M. nivea, M. mollii, M. ochracea, and $M$. sinensis (Fig. 1). Morphologically, M. chiangmaiensis is similar to M. ochracea in having flattened, globose to subglobose base, white stromata, widely open orifices. However, some specimens containing the anamorphic stromata of $M$. chiangmaiensis are hat-shaped, producing pale yellow conidial masses (Fig. 2 a), while M. ochracea produces yellowish orange to orange conidial masses (Chaverri et al. 2008). Additionally, the perithecia in $M$. chiangmaiensis are slightly wider than those reported for other species (Table 3 ) and have various shapes and position of the conidiomata in the stromata

(Fig. 2 a-d). It distinctly produces cream masses of conidia on the colonies on PDA (Fig. 2 n).

Moelleriellaflava Khonsanit, Noisripoom, Phosrithong \& Luangsa-ard, sp. nov. Fig. 3

\section{MycoBank. MB835904}

Anamorph. Aschersonia-like.

Etymology. From the Latin 'flava' meaning yellow. Refers to the yellow stromata of the specimens.

Typification. THAILAND. Nakhon Ratchasima Province, Khao Yai National Park, Mo Sing To Nature Trail; $14^{\circ} 26^{\prime} 21.46^{\prime \prime} \mathrm{N}$, 101²2'20.20"E; on scale insects (Coccidae), found on the underside of Ardisia sanguinolenta leaves; 9 Jan. 2013 ; A. Khonsanit, S. Mongkolsamrit, W. Noisripoom (holotype BBH33722, ex-type living culture BCC60924).

Description.Anamorphic stromata flat to umbonate, globose to subglobose, 1-4.5 mm in diam, pale greenish yellow (2D) to brilliant greenish yellow (1A), strong orange yellow conidial masses (163B). Only one conidioma per stroma, narrowly Ushaped, widely open orifice, 370-600 × 100-300 $\mu \mathrm{m}$. Phialides hyaline, cylindrical, (10-)13-20(-22) × $1.5 \mu \mathrm{m}$. Conidia hyaline, fusiform, (9-)10.5-12.5(-14) × (1-)1.5-2 $\mu \mathrm{m}$. Paraphyses present, hyaline, filiform, up to $173 \mu \mathrm{m}$ long, 1-1.5 $\mu \mathrm{m}$ wide. Teleomorphic stromata flat to umbonate, globose to subglobose, $2.5-4.5 \mathrm{~mm}$ in diam, pale greenish yellow (1D) to brilliant greenish yellow (1A). Perithecia scattered or fused together, semi-embedded, numerous perithecia per stroma $\left({ }^{3} 10\right)$, occasionally developing singly in stroma, obpyriform, 260-430 $\times$ 90-170 $\mu \mathrm{m}$. Ostioles strong orange (N136B) to dark orange

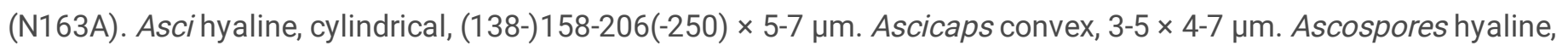
disarticulating into part-spores, cylindrical with truncated ends (6-)7-10.5(-11) $\times$ 1-1.5 $\mu \mathrm{m}$. The teleomorph and anamorph are rarely found in the same stroma. 
Culture characteristics. Colonies on PDA forming a compact mycelium, pulvinate, wrinkled surface, attaining a diam of 8.5$11 \mathrm{~mm}$ in $2 \mathrm{wk}$, white, pale yellow green (4D) conidial masses. Colony reverse moderate yellow (160A), pale yellow in the margins (160D).

Habitat. On scale insects (Coccidae), found only on underside of Ardisia sanguinolenta leaves.

Additional specimens examined. THAILAND, Nakhon Ratchasima Province, Khao Yai National Park, Mo Sing To Nature Trail; $14^{\circ} 26^{\prime} 21.46 " \mathrm{~N}, 101^{\circ} 22^{\prime} 20.20^{\prime \prime} \mathrm{E}$; on scale insects (Coccidae), found on the underside of Ardisia sanguinolenta leaves; 9 Jan. 2013; A. Khonsanit, S. Mongkolsamrit, W. Noisripoom (BBH33722, BCC60925; BBH33723, BCC60926; BBH33724, BCC60927, BCC60928; BBH38474, BCC60929, BCC60930).

Notes.Moelleriella flava differs from other related species in producing yellow stromata (Fig. 3 a-d) and found only one side of conidioma on the stromata (Fig. 3 a-b, e-f). Moelleriella flava produces narrow obpyriform perithecia (Fig. 3 j-k) and longer asci than other species (Table 3). It is found on scale insects feeding only on Ardisia sanguinolenta leaves.

Moelleriella kanchanaburiensis Khonsanit, Mongkolsamrit, Noisripoom, Phosrithong Luangsa-ard sp. nov. Fig. 4

\section{MycoBank. MB835906}

Anamorph. Aschersonia-like.

Etymology. Refers to the place where the type specimen was found, Kanchanaburi Province.

Typification. THAILAND .Kanchanaburi Province, Takhian Thong Waterfall Nature Trail; 15.314651"N, 98.442993"E; on scale insects (Coccidae), found on the underside of bamboo leaves; 20 Nov. 2014; A .Khonsanit, D. Thanakitpipattana, K. Tasanathai, P. Srikitikulchai, .R Promharn, S. Mongkolsamrit, S. Wongkanoun, W. Noisripoom (holotype BBH40814, ex-type living culture BCC75981)

Description.Anamorphic stromata flat to umbonate, globose to subglobose, 1-7 in diam, 1-1.5 mm in thick, white, light yellow (17D) to strong orange yellow (17A) conidial masses. Conidiomata scattered around the center of stromata, widely open orifice, irregular or U-shaped, 200-350 × 150-250 $\mu \mathrm{m}$. Phialides hyaline, cylindrical, (10-)11.5-36.5(-50) × 1-1.5 $\mu \mathrm{m}$. Conidia hyaline, narrowly fusiform with thickened wall at ends, 10-12.5(-14) $\times 1.5-2 \mu \mathrm{m}$. Paraphyses present, hyaline, filiform, up to $110 \mu \mathrm{m}$ long, 1-1.5 $\mu \mathrm{m}$ wide. Teleomorphic stromata raised, 2-3 mm in diam, white. Perithecia scattered, semi-embedded, numerous perithecia per stroma ( ${ }^{35}$ ). Ostioles pale green (151D). The teleomorph of $M$. kanchanaburiensis is immature, we could not observe the size and shape of perithecia, asci, asci caps and ascospores. The teleomorph and anamorph are occasionally found in the same stroma.

Culture characteristics. Colonies on PDA forming a compact mycelium, convex to pulvinate, flat in the margins, attaining a diam of 9.5-11 mm in $2 \mathrm{wk}$, white with brilliant greenish yellow (1B) conidial masses. Colony reverse brilliant greenish yellow (1B), white in the margins.

Habitat. On scale insects (Coccidae), found on the underside of bamboo and dicotyledonous leaves.

Additional specimens examined. THAILAND. Kanchanaburi Province, Takhian Thong Waterfall Nature Trail; $15^{\circ} 18^{\prime} 1.21^{\prime \prime} \mathrm{N}$, 98 $26^{\prime} 54.90^{\prime \prime} \mathrm{E}$; on scale insect (Coccidae), found on dicotyledonous leaves; 20 Nov. 2014; A. Khonsanit, D.

Thanakitpipattana, K. Tasanathai, P. Srikitikulchai, R. Promharn, S. Mongkolsamrit, S. Wongkanoun, W. Noisripoom (BBH40813, BCC75979, BCC75980).

Notes. Moelleriella kanchanaburiensis is found occurring on scale insects on the underside of bamboo and dicotyledonous leaves. The anamorph produces narrowly fusiform conidia with thickened ends appearing as yellow conidial masses in culture. This species can be easily distinguished from other Moelleriella species in producing multiple conidiomatal orifices 
on around the center of stromata surrounding the scale insects. Additionally, the phialides in $M$. kanchanaburiensis are longer than other Moelleriella species (Table 2).

Moelleriella nanensis Khonsanit, Noisripoom, Phosrithong \& Luangsa-ard, sp. nov. Fig. 5

\section{MycoBank. MB835907}

Anamorph. Aschersonia-like.

Etymology. Refers to the locality where the type specimen was found, Nan Province.

Typification. THAILAND. Nan Province, Doi Mongkhon Nature Trail; $18^{\circ} 46^{\prime} 32.27^{\prime \prime} \mathrm{N}, 100^{\circ} 46^{\prime} 22.95^{\prime \prime} \mathrm{E}$; on scale insects (Coccidae), found on the upper side of dicotyledonous leaves; 25 Jul. 2013; A. Khonsanit (holotype BBH36571, ex-type living culture BCC66303).

Description.Anamorphic stromata flattened to raised, globose to subglobose, 2-6 $\mathrm{mm}$ in diam, white, pale greenish yellow conidial masses (160C). Conidiomata scattered around the margins of stromata, irregular in shape, widely open orifices,

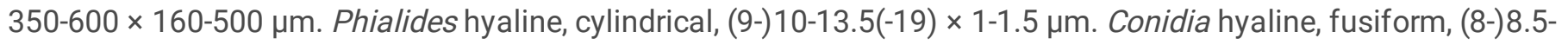
10.5(-11) $\times(1-) 1.5-2 \mu \mathrm{m}$. Paraphyses present, hyaline, filiform, up to $110 \mu \mathrm{m}$ long. 1-1.5 $\mu \mathrm{m}$ wide. Teleomorphic stromata raised to convex, globose to subglobose, 3-6 $\mathrm{mm}$ in diam, white. Perithecia scattered, semi-embedded, perithecia fused together, numerous perithecia per stroma ( $\left.{ }^{3} 20\right)$, obpyriform, 310-550 $\times 110-180 \mu \mathrm{m}$. Ostioles moderate yellow (160A) to strong greenish yellow (151A). Asci hyaline, cylindrical, (105-)161.5-224.5(-238) × (5-)5.5-9.5(-12) $\mu \mathrm{m}$. Asci caps umbonate, 2-4 × 3.5-6 $\mu \mathrm{m}$. Ascospores hyaline, disarticulating into part-spores, cylindrical with rounded ends, slightly indented in the middle, (7-)8-13(-18) $\times(1-) 1.5-2 \mu \mathrm{m}$. The teleomorph and anamorph are present in the same stroma.

Culture characteristics. Colonies on PDA forming a compact mycelium, convex, surface wrinkled and flat in the margins, attaining a diam of 8-9 mm in $3 \mathrm{wk}$, white, pale yellow (160D) conidial masses. Colony reverse light greyish olive (197C), greyish yellow green (197D) at the margins.

Habitat. On scale insects (Coccidae), found on the upper side of dicotyledonous leaves.

Additional specimens examined. THAILAND. Nan Province, Doi Mongkhon Nature Trail; 1846'32.27"N, 10046'22.95"E; on scale insects (Coccidae), found on the upper side of dicotyledonous leaves; 25 July 2013; A. Khonsanit (BBH36571, BCC66304, BCC66305).

Notes. Phylogenetically, M. nanensis is closely related to M. nivea (Fig. 1) and is found on the upper side of dicotyledonous leaves. It differs from M. nivea and other species in producing longer obpyriform perithecia (Fig. $5 \mathrm{j}$ ), umbonate asci caps (Fig. $5 \mathrm{I}$ ) and ascospores that are slightly indented in the center (Fig. $5 \mathrm{~m}$ ). The conidiomatal orifice in M. nanensis could be found surrounding the outer parts of the stroma (Fig. 5 b-c) while in most species the orifices are situated in the center of stromata.

Moelleriella nivea Khonsanit, Mongkolsamrit, Noisripoom, Phosrithong \& Luangsa-ard, sp. nov. Fig. 6

\section{MycoBank. MB835908}

Anamorph. Aschersonia-like.

Etymology. From the Latin 'nivea' meaning white. Refers to the white stromata of the specimens.

Typification.THAILAND. Surat Thani Province, Khao Sok National Park, Wing Hin Waterfall Nature Trail; 854'55.64"N, 98 $31^{\prime} 42.25^{\prime \prime}$, on scale insects (Coccidae), found on dicotyledonous leaves; 28 Nov. 2012; A. Khonsanit, D.

Thanakitpipattana, K. Tasanathai, P. Srikitikulchai, W. Noisripoom (holotype BBH33037, ex-type living culture, BCC60891). 
Description.Anamorphic stromata flat to umbonate, subglobose, 1-5 mm in diam, 1-1.5 $\mathrm{mm}$ in thick, white, brilliant yellow (14C) conidial masses. Conidiomata aggregated on the center of stromata, few conidiomata per stromata (2-5), U-shaped, rim around the orifice thick, narrow widely open orifices, 280-420 × 120-300 $\mu \mathrm{m}$. Phialides hyaline, cylindrical, 11-15 × 1 $\mu \mathrm{m}$. Conidia hyaline, fusiform, (7-)8-9.5(-10) $\times(1-) 1.5-2 \mu \mathrm{m}$. Paraphyses present, hyaline, filiform, up to $57 \mu \mathrm{m}$ long, 1$1.5 \mu \mathrm{m}$ wide. Teleomorphic stromata flat to umbonate, subglobose, 3-3.5 mm in diam, white. Perithecia scattered, semiembedded, occasionally developing singly in stromata, numerous perithecia per stroma ( ${ }^{35}$ ), obpyriform, 260-420 $\times 110-$

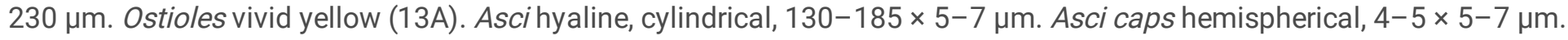
Ascospores hyaline, disarticulating into part-spores, cylindrical with rounded ends, $(5-) 7-10(-10.5) \times 1-1.5(-2) \mu \mathrm{m}$. The teleomorph and anamorph are present in the same stroma.

Culture characteristics. Colonies on PDA forming a compact mycelium, convex to pulvinate, flat in the margins, attaining a diam of 8-9 mm in 2 wk, white, yellowish white (N155A) conidial masses. Colony reverse pale yellow (162D) with white at the margins.

Habitat. On scale insects (Coccidae), found on dicotyledonous leaves.

Additional specimens examined. THAILAND. Surat Thani Province, Khao Sok National Park, Wing Hin Waterfall Nature Trail; $8^{\circ} 54^{\prime} 55.64^{\prime \prime} \mathrm{N}, 98^{\circ} 31^{\prime} 42.25^{\prime \prime E}$, on scale insect (Coccidae), found on dicotyledonous leaves; 28 Nov. 2012; A. Khonsanit, D. Thanakitpipattana, K. Tasanathai, P. Srikitikulchai, W. Noisripoom (BBH33037, BCC58525; BBH33046, BCC58543, BCC58544)

Notes. Moelleriella nivea and M. nanensis are phylogenetically close but $M$. nivea differs from $M$. nanensis in having smaller stromata. The perithecia, asci and part-spores of $M$. nivea are also shorter than reported in M. nanensis (Table 3). In M. nanensis, the perithecia are fused together in the stromata (Fig. $5 \mathrm{~d}$ ) while in M. nivea the perithecium develops singly in stromata (Fig. 6 c-d). M. nivea produces hemispherical asci caps (Fig. 6 k), while in M. nanensis it is umbonate (Fig. 5 k-I). The conidiomata in $M$. nivea are aggregated in the center of stromata (Fig. 6 a-b), almost like a bended tubercle with a cylindrical cavity and a narrow orifice while in $M$. nanensis the conidiomata are scattered around the margins with irregular in shape (Fig. 5 b-c).

Moelleriellasinensis Qiu \& Chen, Phytotaxa 429(4): 289-296 (2020). Fig. 7

The description below is based on Thai materials.

Description.Anamorphic stromata flat to umbonate, cottony, globose to subglobose, slightly convex with wide base, 2-6 mm in diam, white with vivid yellow (17C) conidial masses. Conidiomata scattered in the middle of stromata, elongate flask shaped, narrow orifices, 180-300 × 100-160 $\mu \mathrm{m}$. Phialides hyaline, cylindrical, 11-21 × 1-1.5 $\mu \mathrm{m}$. Conidia hyaline, fusiform, (6.5-)7.5-10(-12) × (1-)1.5-2 $\mu \mathrm{m}$. Paraphyses present, hyaline, filiform, up to $100 \mu \mathrm{m}$ long. 1-1.5 $\mu \mathrm{m}$ wide. Teleomorphic stromata flat to umbonate, globose to subglobose, slightly convex with wide base, 3-6 mm in diam, white to pale yellow (8D). Perithecia scattered, semi-embedded, most perithecia fused together, occasionally developing singly in stromata, numerous perithecia per stroma ( $\left.{ }^{3} 15\right)$, obpyriform, 270-480 × 130-260 $\mu \mathrm{m}$. Ostioles white greenish yellow (7D) to brilliant yellow (20A). Asci hyaline, cylindrical, (161-)178.5-211.5(-238) × (6-)6.5-9(-11) $\mu \mathrm{m}$. Asci caps hemispherical, 3-5 × 4-6.5 $\mu \mathrm{m}$. Ascospores hyaline, disarticulating into part-spores, cylindrical with rounded ends, (7-)8-14.5(-26) $\times 1-2 \mu \mathrm{m}$. The teleomorph and anamorph are present in the same stroma.

Culture characteristics. Colonies on PDA forming a compact mycelium, convex to pulvinate, flat in the margins, wrinkled surface, attaining a diam of 9-10 mm in $2 \mathrm{wk}$, white, light greenish yellow (5D) conidial masses. Colony reverse pale yellow $(160 \mathrm{~A})$, pale greenish yellow (160C) at the margins.

Habitat. On scale insects (Coccidae), found on the upper side of dicotyledonous leaves. 
Specimens examined. THAILAND, Nakhon Ratchasima Province, Khao Yai National Park, Mo Sing To Nature Trail, $14^{\circ} 26^{\prime} 21.46^{\prime \prime} \mathrm{N}, 101^{\circ} 22^{\prime} 20.20^{\prime \prime} \mathrm{E}$; on scale insects (Coccidae), found on the underside of dicotyledonous leaves; 9 Jan. 2013; D. Thanakitpipattana, K. Tasanathai, P. Srikitikulchai, R. Promharn (BBH33725, BCC 60931, BCC 60932); Chiang Mai Province, Doi Inthanon National Park, Mae Chaem Junction (KM.38) Nature Trail; $18^{\circ} 35^{\prime} 15.66^{\prime \prime} \mathrm{N}, 9^{\circ} 29^{\prime} 11.69^{\prime \prime} \mathrm{E}$; on scale insects (Coccidae), found in the underside of dicotyledonous leaves; 28 Oct. 2013; A. Khonsanit, D. Thanakitpipattana, K. Tasanathai, P. Srikitikulchai, W. Noisripoom (BBH38467, BCC69128; BBH38468, BCC69129); Kanchanaburi Province, Thung Yai Naresuan Wildlife Sanctuary (West), Krathon Ruesi Nature Trail, $15^{\circ} 20^{\prime} 0.11^{\prime \prime} \mathrm{N}, 98^{\circ} 54^{\prime} 59.34^{\prime \prime} \mathrm{E}$; on scale insects (Coccidae), found on the underside of dicotyledonous leaves; 18 Nov. 2014; A. Khonsanit, D. Thanakitpipattana, K. Tasanathai, P. Srikitikulchai, R. Promharn, S. Mongkolsamrit, S. Wongkanoun, W. Noisripoom (BBH40812, BCC75977)

Notes. Moelleriellasinensis was first proposed by Chen et al. (2020) on whitefly nymphs (Hemiptera) found from Wu Yi Mountain, Fujian province, southeastern China. Only the anamorphic state was described and illustrated therein. This species was nested in a group in Moelleriella clade A subclade I (Fig. 1). In our study, we describe and illustrate the teleomorphic state of $M$. sinensis found on scale insects (Coccidae). Phylogenetically, M.sinensis is closely related to $M$. nivea, M. nanensis, M. ochracea and M. mollii. Moelleriellasinensis differs from other closely related species in producing longer part spores (see Table 3) and elongate flask-shaped conidiomata with narrow orifices in the center of stromata, while in the other species the orifices are widely open.

\section{Discussion}

The genus Moelleriella was divided into two, Effuse and Globose, clades by Chaverri et al. (2005b, 2008). The Effuse clade comprises species with effuse to thin, pulvinate, mostly white, occasionally pale yellow to orange stromata, occasionally large conidia and produces small part-spores. The Globose clade comprises species with globose, darker yellow to brownish stromata, small conidia and occasionally large part-spores. However, these characters are not unique for each group and can be found overlapping between clades (Chaverri et al. 2008).

In our multigene phylogenetic analyses based on large subunit of the ribosomal DNA (LSU), translation elongation factor$1 \mathrm{a}(T E F)$ and the largest subunit of RNA polymerase II (RPB1) combined with morphological observations of 18 Thai samples of Moelleriella with aschersonia-like anamorphs, five new species in Moelleriella in Clade A subclade I were proposed, namely M. chiangmaiensis (Fig. 2), M. flava (Fig. 3), M. kanchanaburiensis (Fig. 4), M. nanensis (Fig. 5) and M. nivea (Fig. 6). These new species are morphologically and genetically distinct from closely related species such as $M$. mollii, M. ochracea, M. phukhiaoensis, M. pongdueatensis and M. zhongdongii. Furthermore, we describe and illustrate for the first time the teleomorphic state of $M$. sinensis in Thailand. These Moelleriella species in subclade I (Fig.1) mostly have flat to umbonate, globose to subglobose stromata of its anamorphic state. The teleomorphs have mostly semi-embedded perithecia, except for M. phukhiaoensis and M. zhongdongii which have completely embedded perithecia. Moelleriella pongdueatensis and M. kanchanaburiensis were described only based on the anamorphic state. Moelleriella zhongdongii has thick pulvinate stromata with constricted base (Liu and Hodge 2005). Furthermore, most of the species in this clade have whitish stromata, except for M. flava, M. phukhiaoensis and M. pongdueatensis which possess pale-yellow to yellow stromata. Moelleriellasinensis was first reported only for the anamorphic state from China (Chen et al. 2020), and was described as having whitish to pale yellow, pulvinate stroma, and pale brown conidial mass. However, the Thai specimen containing the anamorphic state of $M$. sinensis has white, flat to umbonate stromata, and vivid yellow conidial masses (Fig. 7).

Subclade II includes 10 known species viz. M. alba, M. basicystis, M. chumphonensis, M. disjuncta, M. evansii, M. libera, M. phyllogena, $M$. raciborskii, M. rhombispora and M. umbospora. The shape of anamorphic stromata in this subclade are mostly flat to thin-pulvinate. The teleomorphic stromata produce two kinds of perithecial arrangement. They are produced single tubercles in the stromata for M. alba, M. chumphonensis, M. evansii, M. libera and M. raciborskii, while in M. basicystis, M. disjuncta, M. phyllogena, M. rhombispora and M. umbospora the perithecia are completely embedded in the 
thick-pulvinate or stud-shaped stromata. All members of this subclade II produce yellow stromata except for M. alba which has whitish stromata.

Clade B includes nine known species viz. M. africana, M. boliviensis, M. epiphylla, M. insperata, M. macrostroma, M. reineckiana, M. schizostachyi, M. sloaneae and M. turbinata. All species in this clade are found in the Globose clade after Chaverri et al. (2008); they have globose, large, hard and tuberculate stromata, compact tissue, except $M$. sloaneae which has effuse or thin pulvinate stromata. All species have fully embedded perithecia in the telemorphic state, except for $M$. insperata which the teleomorphic state has not been discovered yet. The stromatal colors in this clade are in darker shades, except for M. sloaneae which is white. In this paper, we found that the position of conidiomata and shape of its orifices are good diagnostic characters in species delimitation for Thai Moelleriella species in the clade A subclade I. The conidiomata of $M$. chiangmaiensis are scattered, irregular in shaped, having widely open orifices with thick rims (Fig. 2). Moelleriella flava has only one conidioma on the stromata, narrowly U-shaped, widely open orifices with thin edges (Fig. 3). Moelleriella kanchanaburiensis has scattered conidiomata in the center and effused in the margins of stromata, irregularly shaped, with widely open orifices (Fig. 4). Moelleriella nanensis has scattered conidiomata around the margins of stromata, irregularly shaped, with widely open orifices (Fig. 5). The conidiomata of M. nivea were aggregated in the middle of stromata (2-5 conidiomata per stroma), prominent from stromatal surfaces with irregular edges, cylindrical in shape, narrow orifices (Fig. 6). Moelleriellasinensis has scattered conidiomata in the middle of stromata, elongate flask shaped, with narrow orifices (Fig.7). Thus, we consider the position of conidiomata and its orifices useful in differentiating Thai Moelleriella species. Similarly, in Aschersoniaandropogonis and $A$. incrassata the presence or absence of a rim around the orifice can be used in differentiating species (Liu et al. 2006). Moelleriella turbinata has a unique character of having pezizoid conidiomata and small orifices (Liu et al. 2006, Chaverri et al. 2008).

The insect hosts in this genus are found in two hemipteran families, Aleyrodidae and Coccidae (Hemiptera) (Petch 1921; Petch 1932; Liu and Hodge 2005; Liu et al. 2006, Chaverri et al. 2008; Tadych et al. 2009; Mongkolsamrit et al. 2011b; Mongkolsamrit et al. 2015; Li et al. 2016; Chen et al. 2020). However, in the study presented here we only found the hosts as scale insects (Coccidae).

\section{Declarations}

Conflict of interest The authors declare that they have no conflict of interest.

Data availability All sequence data generated in this study (see Table 1) are available in GenBank (https://www.ncbi.nlm.nih.gov/genbank/).

\section{Acknowledgements}

We gratefully acknowledge the Royal Forest Department of Thailand, Department of National Parks, Wildlife and Plant Conservation of Thailand (DNP) for permission to survey and collect insect fungi in national parks and wildlife sanctuaries. We thank the staff of Plant Microbe Interaction Research Team (APMT members; Boonchan Thongnuch, Donnaya Thanakitpipattana, Jiranan Techaprasarn, Kanoksi Tasanathai and Rachada Promharn) for collecting samples and providing specimens and cultures. We also thank Dr. Noppol Kobmoo for editing the manuscript.

\section{Funding information}

This study was supported by the National Center for Genetic Engineering and Biotechnology (BIOTEC) Platform Technology Management (Grant no. P19-50231)

\section{Authors' contribution}


The samples in this study were collected by A. Khonsanit, J.J. Luangsa-ard, S. Mongkolsamrit, W. Noisripoom and APMT members. Mophological investigations were observed and illustrated by A. Khonsanit. The insect hosts were identified by N. Phosrithong. Description of the new and known species were described by A. Khonsanit and S. Mongkolsamrit.

Molecular data and phylogenetic analyses were performed by W. Noisripoom. A. Khonsanit and S. Mongkolsamrit wrote the original draft, review and editing were performed by A. Khonsanit, S. Mongkolsamrit and J.J. Luangsa-ard. All authors have read and approved the manuscript.

\section{References}

1. Chaverri P, Bischoff JF, Evan HC, Hodge KT (2005a) Regiocrella, a new entomopathogenic genus with a pycnidial anamorph and its phylogenetic placement in the Clavicipitaceae. Mycologia 97(6):1225-1237. https://doi.org/10.3852/mycologia.97.6.1225

2. Chaverri P, Bischoff JF, Hodge KT (2005b) A new species of Hypocrella, H. macrostroma, and its relationship to other species with large stromata. Mycological Research 109:126-1275. https://doi.org/10.1017/S0953756205003904

3. Chaverri P, Liu M, Hodge KT (2008) A monograph of the entomopathogenic genera Hypocrella, Moelleriella and Samuelsia gen nov.(Ascomycota, Hypocreales, Clavicipitaceae) and their aschersonia-like anamorphs in the Neotropics. Studies in Mycology 60:1-66. https://doi.org/10.3114/sim.2008.60.01

4. Chen YX, Xue QL, XIE YX, Keyhani NO, Guan XY, Wei XY, Zhao J, Yan Z, Chen H, Qui JZ, Guan X (2020) Moelleriella sinensis sp. nov. (Clavicipitaceae, Ascomycota) from southeast China. Phytotaxa 429(4):289-296. https://doi.org/10.11646/phytotaxa.429.4.5

5. Hall TA (2013) BioEdit: a user-friendly biological sequences alignment editor analysis program for windows 95/98/NT. Nucleic Acids Symp Ser 41:95-98

6. Hywel-Jones NL, Evans HC (1993). Taxonomy and ecology of Hypocrella discoidea and its anamorph, Aschersonia samoensis. Mycological Research 97:871-876

7. Hywel-Jones NL, Samuels GJ (1998) Three species of Hypocrella with large stromata pathogenic on scale insects. Mycologia 90:36-46

8. Johnson D, Sung GH, Hywel-Jones NL, Luangsa-ard JJ, Bischoff JF, Kepler RM, Spatafora JW (2009) Systematics and evolution of the genus Torrubiella (Hypocreales, Ascomycota). Mycological Research 113:279-289.

https://doi.org/10.1016/j.mycres. 2008.09.008

9. Li GJ, Hyde KD, Zhao RL, Hongsanan S, Abdel-Aziz FA, Abdel-Wahab MA, Alvarado P, Alves-Silva G, Ammirati JF, Ariyawansa HA, Baghela A, Bahkali AH, Beug M, Bhat DJ, Bojantchev D, Boonpratuang T, Bulgakov TS, Camporesi E, Boro MC, Ceska O, Chakraborty D, Chen JJ, Chethana KWT, Chomnunti P, Consiglio G, Cui BK, Dai DQ, Dai YC, Dinushani A. Daranagama DA, Das K, Dayarathne MC, Crop ED, De Oliveira RJV, Fragoso de Souza CA, Souza JId, Dentinger BTM, Dissanayake AJ, Mingkwan D, Drechsler-Santos ER, Ghobad-Nejhad M, Gilmore SP, Góes-Neto A, Gorczak M, Haitjema CH, Hapuarachchi KK, Akira Hashimoto A, He1 MQ, Henske JK, Hirayama K, Iribarren MJ, Jayasiri SC, Jayawardena RS, Jeon SJ, Jerônimo GH, Jesus AL, Jones EBG, Kang JC, Karunarathna SC, Kirk PM, Konta S, Kuhnert E, Langer E, Lee HS, Lee HB, Li WJ, Li XH, Liimatainen K, Lima DX, Lin CG, Liu JK, Liu XZ, Liu ZY, Luangsa-ard JJ, Lücking R, Lumbsch HT, Lumyong S, Leaño EM, Marano AV, Matsumura M, McKenzie EHC, Mongkolsamrit S, Mortimer PE, Nguyen TTT, Niskanen T, Norphanphoun C, O’Malley MA, Parnmen S, Pawłowska J, Perera RH, Phookamsak R, Phukhamsakda C, Pires-Zottarelli CLA, Raspé O, Reck MA, Rocha SCO, Santiago ALCMAd, Senanayake IC, Setti L, Shang QJ, Singh SK, Esteban B. Sir EB, Solomon KV, Song J, Srikitikulchai P, Stadler M, Suetrong S, Takahashi H, Takahashi T, Tanaka K, Tang LP, Thambugala KM, Thanakitpipattana D, Theodorou MK, Thongbai B, Thummarukcharoen T, Tian Q, Tibpromma S, Verbeken A, Vizzini A, Vlasák J, Voigt K, Wanasinghe DN, Wang Y, Weerakoon G, Wen HA, Wen TC, Wijayawardene NN, Wongkanoun S, Wrzosek M, Xiao YP, Xu JC, Yan JY, Yang J, Yang SD, Hu Y, Zhang JF, Zhao J, Zhou LW, Peršoh D, Phillips AJL, Maharachchikumbura SSN (2016) Fungal diversity notes 
253-366: taxonomic and phylogenetic contributions to fungal taxa. Fungal Diversity 78:1-237.

https://doi.org/10.1007/s13225-016-0366-9

10. Khonsanit A, Luangsa-ard JJ, Thanakitpipattana D, Noisripoom W, Chaitika T, Kobmoo N (2020) Cryptic diversity of the genus Beauveria with a new species from Thailand. Mycological Progress 19:291-315.

https://doi.org/10.1007/s11557-020-01557-9

11. Liu M, Chaverri P, Hodge KT (2006) A taxonomic revision of the insect biocontrol fungus Aschersonia aleyrodis, its allies with white stromata and their Hypocrella sexual states. Mycological research 110:537-554.

https://doi.org/10.1016/j.mycres.2006.01.013

12. Liu M, Hodge KT (2005) Hypocrella zhongdongii sp. nov., the teleomorph of Aschersonia incrassa. Mycological research 109(7):818-824. https://doi.org/10.1017/S09537562050 0290

13. Luangsa-ard JJ, Mongkolsamrit S, Noisripoom W, Thanakitpipattana D, Khonsanit A, Wutikhun T (2017) Helicocollum, a new clavicipitalean genus pathogenic to scale insects (Hemiptera) in Thailand. Mycological Progress 16:419-431. https://doi.org/10.1007/s1 1557-017-1283-3

14. Luangsa-ard JJ, Tasanathai K, Mongkolsamrit S, Hywel-Jones NL (2008) Atlas of Invertebrate -Pathogenic Fungi of Thailand Volume 2. National Center for Genetic Engineering and Biotechnology, National Science and Technology Development Agency, Pathum Thani

15. Luangsa-ard JJ, Tasanathai K,Mongkolsamrit S, Hywel-Jones NL (2012) Atlas of Invertebrate-Pathogenic Fungi of Thailand Volume 4. National Center for Genetic Engineering and Biotechnology, National Science and Technology Development Agency, Pathum Thani

16. Mains EB (1959a) Species of Aschersonia (Sphaeropsidales). Lloydia 22:215-221

17. Mains EB (1959b) Species of Hypocrella. Mycopathologia et Mycologia Applicata 11:311-326

18. Mongkolsamrit S, Khonsanit A, Noisripoom W, Luangsa-ard JJ (2015) Two new entomogeno us species of Moelleriella with perithecia in tubercles from Thailand. Mycoscience 56:66-74. https://doi.org/10.1016/ j.myc.2014.03.002

19. Mongkolsamrit S, Luangsa-ard JJ, Tasanathai K, Sivichai S (2010) Invertebrate-Pathogenic Fungi of Thailand, National Center for Genetic Engineering and Biotechnology, National Science and Technology Development Agency, Pathum Thani

20. Mongkolsamrit S, Luangsa-ard JJ, Hywel-Jones NL (2011a) Samuelsia mundiveteris sp. nov. from Thailand. Mycologia 103:921-927

21. Mongkolsamrit S, Nguyen TT, Tran NL, Luangsa-ard JJ (2011b) Moelleriella pumatensis, new entomogenous species from Vietnam. Mycotaxon 117:45-51

22. Mongkolsamrit S, Noisripoom W, Thanakitpipattanaa D, Wutikhunb T, Spatafora JW, Luangsa-ard JJ (2018)

Disentangling cryptic species with isaria-like morphs in Cordycipitaceae. Mycologia 110:230-257.

https://doi.org/10.1080/00275514.2018.144 6651

23. Mongkolsamrit S, Spatafora JW, Luangsa-ard JJ, Sung GH, Hywel-jones NL (2009) A combined ITS rDNA and b-tubulin phylogeny of Thai species of Hypocrella with non-fragmenting ascospores. Mycological Research 113:684-699. https://doi.org/10.1016/ j.mycres.2009.02.004

24. Montagne JPFC (1848) Sixie`me centurie de plantes cellulaires exotiques nouvelles. Crypto gamae Taitenses. Annales des Sciences Naturelles Botanique, Se'rie. 3(10):106-136

25. Page RDM (1996) TreeView: an application to display phylogenetic trees on personal compu ters. Computer Applications in the Biosciences 12:357-358

26. Qiu JZ, Guan X (2010) A new species of Aschersonia (Clavicipitaceae, Hypocreales) from China. Mycotaxon 111:471475

27. Qiu JZ, Ma HF, Wang YY, Guan X (2009) Two Aschersonia species from Fujian new to China. Mycosystema 28:60-63 
28. Petch T (1921) Studies in entomogenous fungi. II. The genera of Hypocrella and Aschersonia. Annals of the Royal Botanic Gardens Peradeniya 7:167-278

29. Petch T (1925) Entomogenous fungi. Addition and correstions. Transactions of the British Mycological Society 10:190201

30. Petch T (1931) Note on entomogenous fungi, 22-48. Transactions of the British Mycological Society 16:55-75

31. Petch T (1932) Notes on entomogenous fungi. Transactions of the British Mycological Society 16:209-245

32. Ronquist F, Teslenko M, Mark P, Ayres D, Darling A, Höhna S, Larget B, Liu L, Suchard M, Huelsenbeck J (2012) MrBayes 3.2:efficient Bayesian phylogenetic inference and model choice across a large model space. Syst Biol 61:539-542. https://doi.org/10.1093/sysbio /sys029

33. Saccardo PA (1878) Enumeratio pyrenomycetum hypocreaceorum. Michelia 1:277-325

34. Stamatakis A (2014) RAxML version 8: a tool for phylogenetic analysis and post-analysis of large phylogenies. Bioinformatics 30(9):1312-1313. https://doi.org/10.1093/bioinforma tics/btu033

35. Sung GH, Hywel-Jones NL, Sung JM, Luangsa-ard JJ, Shrestha B, Spatafora JW (2007) Phylogenetic classification of Cordyceps and the clavicipitaceous fungi. Studies in Mycology 57:5-59. https://doi:10.3114/sim.2007.57.01

36. Tadych M, Chaverri P, Bergen M, White JF (2009) Moelleriella zhongdongii: stroma development and identification of hirsutella-like and Aschersonia synanamorphs. Mycological research 113(5):611-615.

https://doi:10.1016/j.mycres.2009.01.011

37. Tibpromma S, Hyde KD, Jeewon R, Maharachchikumbura SSN, Liu JK, Bhat DJ, Jones EBG, McKenzie EHC, Camporesi E, Bulgakov TS, Doilom M, Monteiro de ASALC, Das K, Manimohan P, Gibertoni TB, Lim YW, Ekanayaka AH, Thongbai B, Lee HB, Yang JB, Kirk PM, Sysouphanthong P, Singh SK, Boonmee S, Dong W, Raj KNA, Latha KP, Phookamsak R, Phukhamsakda C, Konta S, Jayasiri SC, Norphanphoun C, Tennakoon DS, Li J, Dayarathne MC, Perera RH, Xiao Y, Wanasinghe DN, Senanayake IC, Goonasekara ID, Silva NID, Mapook A, Jayawardena RS, Dissanayake AJ, Manawasinghe IS, Chethana KWT, Luo ZL, Hapuarachchi KK, Baghela A, Soares AM, Vizzini A, Meiras-Ottoni A, Mešic' A, Dutta AK, Fragoso de Souza CA, Richter C, Lin CG, Chakrabarty D, Daranagama DA, Lima DX (2017) Fungal diversity notes 491-602: taxonomic and phylogenetic contributions to fungal taxa. Fungal Diversity 83:1-261. https://10.1007/s13225-017-0378-0

38. Yuan HS, Lu X, Dai YC, Hyde KD, Kan YH, KuH, I, He SH, Liu NG, Sarma VV, Zhao CL, Cui BK, Yousaf N, Sun G, Liu SY, Wu F, Lin CG, Dayarathne MC, Gibertoni TB, Concei LB, Garibaynie of R, Villegasie of M, Salasgasie o R, Wei TZ, Qiu JZ, Yu ZF, Phookamsak R, Zeng M, Paloi S, Bao DF, Abeywickrama PD, Wei DP, Yang J, Manawasinghe IS, Harishchandra D, Brahmanage RS, Silva NId, Tennakoon DS, Karunarathna A, Gafforov Y, Pem D, Zhang SN, Santiago ALCMdA, Bezerra JDP, Dima B, Acharya K, Alvarez, hnaa Agr J, Ali H. Bahkali AH, Vinod K. Bhatt VK, Brandrud TE, Bulgakov TS, Camporesi E, Cao T, Chen YX, Chen YY, Devadatha B, Elgorban AM, Fan LF, Du X, Gao L, GonCalves CM, Gusmão LFP, Huanraluek N, Margita Jadan M, Jayawardena RS, Khalid AN, Langer E, Lima DX, Lima rrdena NCd, Lira CRSd, Liu JKJ, Liu S, Lumyong S, Luo ZL, Mato ng N, Niranjan M, Oliveiraenaant JRC, Papp V, Pereziraena E, Phillips AJL, PL, Ren Y, Ruiz RFC, Semwal KC, Soop K, Souza CAFd, Motta CM, Sun LH, Xie ML, YiL, , L, a YJ, Zhao Q, Zhou LW (2020) Fungal diversity notes 1277-1386: taxonomic and phylogenetic contributions to fungal taxa. Fungal Diversity 104:1-266. https://doi.org/10.1007/s13225-020-00461-7

\section{Tables}

Table 1 List of species and GenBank accession numbers of sequences used in this study. 


\begin{tabular}{|c|c|c|c|c|c|}
\hline \multirow[t]{2}{*}{ Species } & \multirow[t]{2}{*}{ Strain } & \multirow[t]{2}{*}{ Origin } & \multicolumn{3}{|c|}{ GenBank Accession no. } \\
\hline & & & nrLSU & TEF & $R P B 1$ \\
\hline Aschersonia discoidea & BCC2097 & Thailand & - & AY986945 & DQ000346 1 \\
\hline Aschersonia cf. discoidea & 193-901d & Ivory Coast & EU392567² & EU392646² & EU392700² \\
\hline Aschersonia disciformis & P.C. 655 & Honduras & EU392560² & EU3926432 & EU3926972 \\
\hline Aschersonia disciformis & P.C. 676 & Honduras & EU392566 2 & EU392645² & EU3926992 \\
\hline Conoideocrella luteorostrata & NHJ11343 & Thailand & EF468850³ & EF46880 3 & $\mathrm{EF} 468906^{3}$ \\
\hline Conoideocrella luteorostrata & NHJ12516 & Thailand & EF468849 3 & EF468800³ & $\mathrm{EF} 468905^{3}$ \\
\hline Conoideocrella tenuis & NHJ6293 & Thailand & EU369044 & EU3690294 & EU369068 ${ }^{4}$ \\
\hline Conoideocrella tenuis & NHJ6791 & Thailand & EU369046 4 & EU3690284 & EU369069 4 \\
\hline Helicocollum surathaniensis & ВСС34463 & Thailand & KT222328 & KT222336 5 & - \\
\hline Helicocollum surathaniensis & ВСС34464 & Thailand & KT222329 & KT2223375 & - \\
\hline Moelleriella africana & P.C. 736 & Ghana & AY986917² & AY9869432 & DQ000344 2 \\
\hline Moelleriella alba & BCC49492 & Thailand & JQ2696456 & $\mathrm{KX} 254424^{6}$ & JQ2569056 \\
\hline Moelleriella alba & BCC49409 & Thailand & JQ2696466 & $K X 254423^{6}$ & JQ2569066 \\
\hline Moelleriella basicystis & P.C. 374 & Costa Rica & AY9869032 & AY986928 2 & DQ000329² \\
\hline Moelleriella boliviensis & P.C. 603 & Bolivia & AY9869232 & AY986950² & DQ000351 ${ }^{2}$ \\
\hline Moelleriella chiangmaiensis & BCC18029 & Thailand & MT659360 & MW091560 & - \\
\hline Moelleriella chiangmaiensis & ВBH33051 & Thailand & MT659362 & MT672277 & MT672269 \\
\hline Moelleriella chiangmaiensis & BCC60941 & Thailand & MT659361 & MT672278 & MT672270 \\
\hline Moelleriella chumphoensis & BCC47575 & Thailand & JQ2696486 & $\mathrm{KX} 254422^{6}$ & $J Q 256908^{6}$ \\
\hline Moelleriella chumphoensis & BCC47574 & Thailand & JQ2696476 & $\mathrm{KX} 254421^{6}$ & JQ2569076 \\
\hline Moelleriella disjuncta & J.B. 205 & Panama & EU392578² & EU392654² & - \\
\hline Moelleriella epiphylla & P.C. 545 & Bolivia & EU392585² & EU392660² & EU392711 2 \\
\hline Moelleriella epiphylla & $193-813$ & Guiana & EU392583² & EU392656² & EU392707² \\
\hline Moelleriella evansii & P.C. 627 & Ecuador & AY986916 2 & AY986942 2 & DQ000343² \\
\hline Moelleriella flava & BCC60924 & Thailand & KF951146 & KX254430 & MT672271 \\
\hline Moelleriella flava & BCC60925 & Thailand & KF951147 & KX254431 & MT672272 \\
\hline Moelleriella flava & BCC60929 & Thailand & KX298238 & KX254432 & MT672273 \\
\hline Moelleriella flava & BCC60930 & Thailand & KX298237 & KX254429 & - \\
\hline Moelleriella gracilispora & CGMCC 3.18989 & China & KC9642027 & KC9641917 & KC9641797 \\
\hline
\end{tabular}




\begin{tabular}{|c|c|c|c|c|c|}
\hline Moelleriella gracilispora & CGMCC 3.18990 & China & KC9642037 & KC9641927 & KC9641807 \\
\hline Moelleriella insperata & ARSEF 2396 & Philippines & AY518374 2 & DQ070029² & EU392713² \\
\hline Moelleriella kanchanaburiensis & BCC75979 & Thailand & MT659363 & MT672279 & MT843900 \\
\hline Moelleriella kanchanaburiensis & BCC75980 & Thailand & MT659364 & MT672280 & MT843901 \\
\hline Moelleriella kanchanaburiensis & BCC75981 & Thailand & MT659365 & MT672281 & - \\
\hline Moelleriella libera & P.C. 444 & Mexico & EU3925912 & EU392662² & EU392714 2 \\
\hline Moelleriella libera & P.C. 445 & Mexico & AY986900² & AY986925 & DQ000326 2 \\
\hline Moelleriella macrostroma & P.C. 605 & Bolivia & $\mathrm{DQ} 000347^{2}$ & AY986946² & AY986919² \\
\hline Moelleriella macrostroma & J.B. 115 & Costa Rica & AY986920² & AY9869472 & DQ000348² \\
\hline Moelleriella mollii & 193-901a & Ivory Coast & EU392599² & EU392667² & EU392719² \\
\hline Moelleriella mollii & 193-901c & Ivory Coast & EU392600² & EU392668² & EU392720 2 \\
\hline Moelleriella nanensis & BCC66303 & Thailand & KX298236 & KX254427 & MW085940 \\
\hline Moelleriella nanensis & BCC66305 & Thailand & MW080317 & KX254428 & MW085941 \\
\hline Moelleriella nivea & BCC60891 & Thailand & MW080318 & MT672282 & MW085942 \\
\hline Moelleriella nivea & BCC58543 & Thailand & MT659366 & MT672283 & MT672274 \\
\hline Moelleriella nivea & BCC58544 & Thailand & MT659367 & MT672284 & MT843898 \\
\hline Moelleriella ochracea & IE 1308 & Mexico & EU392601 2 & EU392669² & EU392721 2 \\
\hline Moelleriella ochracea & P.C. 648 & Honduras & EU392605 2 & EU392671 2 & EU392723 2 \\
\hline Moelleriella phukhiaoensis & BCC19769 & Thailand & KT880502 8 & - & KT880506 8 \\
\hline Moelleriella phukhiaoensis & BCC19773 & Thailand & KT880503 ${ }^{8}$ & - & KT880507 ${ }^{8}$ \\
\hline Moelleriella phyllogena & P.C. 555 & Bolivia & EU392610² & EU392674² & EU392726 2 \\
\hline Moelleriella phyllogena & J.B. 130 & Panama & EU392608² & EU392672 2 & EU392724 ${ }^{2}$ \\
\hline Moelleriella pongdueatensis & ВСС31787 & Thailand & KT8805008 & $\mathrm{KX} 254433^{8}$ & KT880504 ${ }^{8}$ \\
\hline Moelleriella pongdueatensis & ВСС31788 & Thailand & KT880501 ${ }^{8}$ & $\mathrm{KX} 254434^{8}$ & KT880505 ${ }^{8}$ \\
\hline Moelleriella raciborskii & BCC48745 & Thailand & - & KX2544206 & $J Q 269642^{6}$ \\
\hline Moelleriella raciborskii & Afr 28 & Ghana & DQ070113² & EU392675² & EU392727 2 \\
\hline Moelleriella raciborskii & P.C. 533 & Vietnam & AY986911² & AY986937² & DQ000338² \\
\hline Moelleriella raciborskii & BCC47597 & Thailand & - & KX254418 & JQ2696446 \\
\hline Moelleriella raciborskii & BCC49361 & Thailand & - & $\mathrm{KX} 254419^{6}$ & $J Q 269643^{6}$ \\
\hline Moelleriella raciborskii & 193-901b & Ivory Coast & EU392611² & EU392676 2 & EU392728 ${ }^{2}$ \\
\hline Moelleriella reineckiana & BCC1713 & Thailand & - & DQ384968 & DQ385008 6 \\
\hline
\end{tabular}

Page 15/29 


\begin{tabular}{|c|c|c|c|c|c|}
\hline Moelleriella reineckiana & BCC1765 & Thailand & - & DQ384958 & DQ385010 6 \\
\hline Moelleriella rhombispora & P.C. 467 & Costa Rica & AY986908² & AY986933² & DQ000334 2 \\
\hline Moelleriella rhombispora & P.C. 696 & Honduras & EU392618² & EU392680² & EU392732 2 \\
\hline Moelleriella schizostachyi & CBS 100067 & Thailand & AY9869212 & AY986948² & DQ000349² \\
\hline Moelleriella sloaneae & $194-920$ & Guatemala & EU392621 2 & EU392682 2 & EU392734 2 \\
\hline Moelleriella sloaneae & 194-922c & Belize & EU392622 2 & EU392683² & EU392735 2 \\
\hline Moelleriella turbinata & P.C. 678 & Honduras & EU392627² & EU392687² & EU392739² \\
\hline Moelleriella turbinata & IMI 352838 & Mexico & EU392625² & EU392685² & EU392737² \\
\hline Moelleriella sinensis & CGMCC3.18911 & China & MK4120919 & MK3938689 & MK412101 ${ }^{9}$ \\
\hline Moelleriella sinensis & BCC60932 & Thailand & MT659368 & - & MT672275 \\
\hline Moelleriella sinensis & BCC69128 & Thailand & KX298234 & KX254425 & MT843899 \\
\hline Moelleriella sinensis & BCC69129 & Thailand & KX298235 & KX254426 & MT672275 \\
\hline Moelleriella umbospora & P.C. 457 & Mexico & AY986904 2 & AY986929² & DQ000330² \\
\hline Moelleriella umbospora & P.C. 461 & Mexico & EU392628² & EU392688² & EU392740 2 \\
\hline Moelleriella zhongdongii & P.C. 504 & Costa Rica & EU3926312 & EU392689² & EU392741 2 \\
\hline Moelleriella zhongdongii & P.C. 549 & Bolivia & EU392632 2 & EU392690² & EU392742 2 \\
\hline Orbiocrella petchii & NHJ6240 & Thailand & EU369038 4 & EU369060 4 & EU369022 4 \\
\hline Orbiocrella petchii & NHJ6209 & Thailand & EU3690394 & EU3690614 & EU3690234 \\
\hline Purpureocillium lilacinum & CBS 284.36 & - & AY $624227^{3}$ & EF468792 3 & $\mathrm{EF} 468898^{3}$ \\
\hline Purpureocillium lilacinum & CBS 431.87 & - & EF468844 & $\mathrm{EF} 468791^{3}$ & $\mathrm{EF} 468897^{3}$ \\
\hline Regiocrella camerunensis & CUP 67512 & Cameroon & DQ118735¹ & DQ118743¹ & DQ127234 \\
\hline Regiocrella sinensis & CUP CH-2640 & China & DQ118736 & DQ118744 & DQ127235 \\
\hline Samuelsia chalalensis & P.C. 560 & Bolivia & EU392637² & EU392691 2 & EU392743² \\
\hline Samuelsia geonomis & P.C. 614 & Bolivia & EU392638² & EU392692² & EU392744 2 \\
\hline Samuelsia mundiveteris & BCC40021 & Thailand & GU552152 & GU552145 & - \\
\hline Samuelsia mundiveteris & BCC40022 & Thailand & GU552153 & GU552146 & - \\
\hline Samuelsia rufobrunnea & P.C. 613 & Bolivia & EU392638 2 & AY986944² & DQ000345 2 \\
\hline
\end{tabular}

The accession numbers marked in bold font refer to sequences new in this study 
References: ${ }^{1}$ Chaverri et al. 2005a, ${ }^{2}$ Chaverri et al. 2008, ${ }^{3}$ Sung et al. 2007, ${ }^{4}$ Johnson et al. $2009{ }^{5}$ Luangsa-ard et al. 2017, ${ }^{6}$ Mongkolsamrit et al. 2015, ${ }^{7}$ Yuan et al. 2020, ${ }^{8}$ Li et al. 2016, ${ }^{9}$ Chen et al 2020.

Table 2 Morphological comparisons between the anamorphs of Moelleriella species. 


\begin{tabular}{|c|c|c|c|c|c|}
\hline Species & Conidiomata & Phialides & Conidia & Paraphyses & References \\
\hline & $(\mu \mathrm{m})$ & $(\mu \mathrm{m})$ & $(\mu \mathrm{m})$ & & \\
\hline Moelleriella alba & $\begin{array}{l}140-200 \times 150- \\
180\end{array}$ & $\leq 22 \times 1-$ & $\begin{array}{l}\text { Fusiform, 8-12 × 1.5- } \\
3\end{array}$ & Absent & $\begin{array}{l}\text { Mongkolsamrit et } \\
\text { al. (2015) }\end{array}$ \\
\hline M. basicystis & - & $\begin{array}{l}5.5-13.5 \times \\
2-3\end{array}$ & $\begin{array}{l}\text { Ventricose, } 11-15.5 \times \\
3-5\end{array}$ & Absent & $\begin{array}{l}\text { Chaverri et al. } \\
(2008)\end{array}$ \\
\hline M. castanea & - & $\begin{array}{l}7-17.5 \times \\
1.5-2\end{array}$ & $\begin{array}{l}\text { Fusiform, } 5-6.7 \times 1.5- \\
2\end{array}$ & Absent & Petch (1932) \\
\hline M. chiangmaiensis & $\begin{array}{l}450-500 \times 150- \\
270\end{array}$ & $\begin{array}{l}8-20 \times \\
1.5-2\end{array}$ & $\begin{array}{l}\text { Fusiform, 7-11 × 1.5- } \\
2\end{array}$ & $\begin{array}{l}\text { Present, } \leq 130 \times \\
1-1.5\end{array}$ & This study \\
\hline $\begin{array}{l}\text { M. } \\
\text { chumphonensis }\end{array}$ & $\begin{array}{l}180-300 \times 130- \\
170\end{array}$ & $\frac{\leq}{2} 22 \times 1-$ & Fusiform, $16-22 \times 2-3$ & Present & $\begin{array}{l}\text { Mongkolsamrit et } \\
\text { al. (2015) }\end{array}$ \\
\hline M. disjuncta & - & $\begin{array}{l}9.5-16 \times \\
1.5-2.5\end{array}$ & $\begin{array}{l}\text { Fusiform, 6.8-9.3 × } \\
2.3-3\end{array}$ & Absent & $\begin{array}{l}\text { Chaverri et al. } \\
(2008)\end{array}$ \\
\hline M. epiphylla & - & $\begin{array}{l}8-12.7 \times \\
2.5-3.5\end{array}$ & $\begin{array}{l}\text { Ovoid, } 9-13.5 \times 3.5- \\
6.5\end{array}$ & Absent & $\begin{array}{l}\text { Chaverri et al. } \\
(2008)\end{array}$ \\
\hline M. evansii & - & $\begin{array}{l}10-17 \times \\
1.5-2\end{array}$ & $\begin{array}{l}\text { Fusiform, } 11.2-15 \times \\
2.5-3.2\end{array}$ & Absent & $\begin{array}{l}\text { Chaverri et al. } \\
\text { (2008) }\end{array}$ \\
\hline M. flava & $\begin{array}{l}370-600 \times 100- \\
300\end{array}$ & $\begin{array}{l}10-22 \times \\
1.5\end{array}$ & Fusiform, 9-14 × 1-2 & $\begin{array}{l}\text { Present, } \leq 173 \times \\
1-1.5\end{array}$ & This study \\
\hline M. globosa & - & - & $\begin{array}{l}\text { Ovoid, } 11.5-14.3 \times \\
4.5-6\end{array}$ & Absent & $\begin{array}{l}\text { Chaverri et al. } \\
(2008)\end{array}$ \\
\hline M. gracilispora & $\begin{array}{l}166-236 \times \\
53-136\end{array}$ & $\begin{array}{l}6-12 \times \\
0.8-1.3\end{array}$ & $\begin{array}{l}\text { Fusiform, } 11-12 \times \\
1-2\end{array}$ & $\begin{array}{l}\text { Present, 36-103 } \\
\times 0.4-0.8\end{array}$ & Yuan et al. (2020) \\
\hline M. guaranitica & - & $\begin{array}{l}14.2-25.2 \\
\times 2-3\end{array}$ & $\begin{array}{l}\text { Fusiform, 9-13.5 × 3- } \\
4\end{array}$ & Absent & $\begin{array}{l}\text { Chaverri et al. } \\
(2008)\end{array}$ \\
\hline $\begin{array}{l}\text { M. } \\
\text { kanchanaburiensis }\end{array}$ & $\begin{array}{l}200-350 \times 150- \\
250\end{array}$ & $\begin{array}{l}10-50 \times 1- \\
1.5\end{array}$ & $\begin{array}{l}\text { Narrowly fusiform, 9- } \\
14 \times 1-2\end{array}$ & $\begin{array}{l}\text { Present, } \leq 110 \times \\
1-1.5\end{array}$ & This study \\
\hline M. libera & - & $\begin{array}{l}10-20 \times 1- \\
1.5\end{array}$ & $\begin{array}{l}\text { Fusiform, 9-18 × 1.5- } \\
2.5\end{array}$ & $\begin{array}{l}\text { Present, } 50-113 \\
\times 1-1.5\end{array}$ & $\begin{array}{l}\text { Chaverri et al. } \\
\text { (2008) }\end{array}$ \\
\hline M. macrostroma & - & - & $\begin{array}{l}\text { Fusiform, } 10.7-14.5 \times \\
2-3\end{array}$ & Absent & $\begin{array}{l}\text { Chaverri et al. } \\
(2005 b)\end{array}$ \\
\hline M. madidiensis & - & $\begin{array}{l}10-20 \times \\
2.5-3\end{array}$ & $\begin{array}{l}\text { Fusiform, 8.5-10.5 } \\
2-2.5\end{array}$ & Absent & $\begin{array}{l}\text { Chaverri et al. } \\
\text { (2008) }\end{array}$ \\
\hline M. mollii & $\leq 300 \times \leq 160$ & - & $\begin{array}{l}\text { Fusiform, } 8-14 \times 1- \\
1.5\end{array}$ & Present, $\leq 60$ & $\begin{array}{l}\text { Hennings (1900), } \\
\text { Petch (1921) }\end{array}$ \\
\hline M. nanensis & $\begin{array}{l}350-600 \times 160- \\
500\end{array}$ & $\begin{array}{l}9-19 \times 1- \\
1.5\end{array}$ & Fusiform, 8-11 × 1-2 & $\begin{array}{l}\text { Present, } \leq 110 \times \\
1-1.5\end{array}$ & This study \\
\hline M. nivea & $\begin{array}{l}280-420 \text { × 120- } \\
300\end{array}$ & $\begin{array}{l}11-15 \times \\
11-1.5\end{array}$ & Fusiform, $7-10 \times 1-2$ & $\begin{array}{l}\text { Present, } \leq 110 \times \\
1-1.6\end{array}$ & This study \\
\hline M. ochracea & $100-600$ diam & $\begin{array}{l}7-16 \times 1- \\
1.5\end{array}$ & $\begin{array}{l}\text { Fusiform, 8-14 × 1.5- } \\
2\end{array}$ & Present & $\begin{array}{l}\text { Chaverri et al. } \\
(2008)\end{array}$ \\
\hline M. phukhiaoensis & $\leq 430 \times \leq 100$ & $\frac{\leq}{2} 25 \times 1-$ & $\begin{array}{l}\text { Cylindrical narrow, } \\
16-17 \times 2.5-3.5\end{array}$ & $\begin{array}{l}\text { Present, } \leq 90 \times \\
1-2\end{array}$ & Li et al. (2016) \\
\hline M. phyllogena & - & $8-10.7 \times$ & Ventricose, $12-18.5 \times$ & Absent & Chaverri et al. \\
\hline
\end{tabular}




\begin{tabular}{|c|c|c|c|c|c|}
\hline & & $2-3$ & $3.2-5$ & & (2008) \\
\hline $\begin{array}{l}\text { M. } \\
\text { pongdueatensis }\end{array}$ & - & $\leq 23 \times 1-$ & $\begin{array}{l}\text { Fusiform, 9-12.5 x } \\
1.5-2.5\end{array}$ & $\begin{array}{l}\text { Present } \leq 110 \times \\
1-2\end{array}$ & Li et al. (2016) \\
\hline M. pumatensis & $\begin{array}{l}250-280 \times 90- \\
100\end{array}$ & $\leq 25$ long & $\begin{array}{l}\text { Fusiform, } 12-15 \times 2 \text { - } \\
2.5\end{array}$ & $\begin{array}{l}\text { Present, } \leq 180 \times \\
1.5\end{array}$ & $\begin{array}{l}\text { Mongkolsamrit et } \\
\text { al. (2011) }\end{array}$ \\
\hline M. rhombispora & - & $\begin{array}{l}8-12 \times \\
1.5-2\end{array}$ & $9-14 \times 2.5-3$ & Present & Liu et al. (2006) \\
\hline M. sinensis & $\begin{array}{l}103.6-279.6 \times \\
83.1-145.5\end{array}$ & $\begin{array}{l}\leq 30 \times \\
0.8-1.3\end{array}$ & $\begin{array}{l}\text { Fusiform, } 6.7-11 \times \\
1.3-1.8\end{array}$ & $\begin{array}{l}\text { Present,43.2- } \\
68.9 \times 0.6-0.8\end{array}$ & Chen et al. (2020) \\
\hline M. sinensis & $\begin{array}{l}180-300 \times 100- \\
160\end{array}$ & $\begin{array}{l}11-21 \times 1- \\
1.5\end{array}$ & $\begin{array}{l}\text { Fusiform, } 6.5-12 \times 1- \\
2\end{array}$ & $\begin{array}{l}\text { Present, } \leq 100 \times \\
1-1.5\end{array}$ & This study \\
\hline M. sloaneae & - & $\begin{array}{l}5.2-19.7 \times \\
1.3-2.5\end{array}$ & $\begin{array}{l}\text { Fusiform, 6.3-14.7 × } \\
1.8-2.8\end{array}$ & Present & $\begin{array}{l}\text { Chaverri et al. } \\
\text { (2008) }\end{array}$ \\
\hline M. turbinata & - & $\begin{array}{l}9-18 \times \\
2.7-6.3\end{array}$ & $\begin{array}{l}\text { Ovoid, } 8-13.5 \times 3.8- \\
6.2\end{array}$ & Absent & $\begin{array}{l}\text { Chaverri et al. } \\
(2008)\end{array}$ \\
\hline M. umbospora & - & $\begin{array}{l}8.5-10 \times \\
2-2.5\end{array}$ & $\begin{array}{l}\text { Ventricose, } 11-15.5 \times \\
3-5\end{array}$ & Absent & $\begin{array}{l}\text { Chaverri et al. } \\
\text { (2008) }\end{array}$ \\
\hline M. zhongdongii & - & $\begin{array}{l}10-70 \times \\
1.5-2\end{array}$ & $\begin{array}{l}\text { Fusiform, } 10-15 \times 1- \\
2.5\end{array}$ & Present & $\begin{array}{l}\text { Liu and Hodge } \\
\text { (2005) }\end{array}$ \\
\hline
\end{tabular}

Table 3 Morphological comparisons between the teleomorphs of Moelleriella species. 


\begin{tabular}{|c|c|c|c|c|c|c|c|c|}
\hline Species & Countries & Host & Stromata & Perithecia & Asci & $\begin{array}{l}\text { Asci- } \\
\text { caps }\end{array}$ & $\begin{array}{l}\text { Part- } \\
\text { spores }\end{array}$ & References \\
\hline & found & & $(\mathrm{mm})$ & $(\mu \mathrm{m})$ & $(\mu \mathrm{m})$ & $(\mu \mathrm{m})$ & $(\mu \mathrm{m})$ & \\
\hline M. alba & Thailand & $\begin{array}{l}\text { Scale } \\
\text { insects, } \\
\text { whiteflies }\end{array}$ & $\begin{array}{l}3-6 \times 1- \\
1.5\end{array}$ & $\begin{array}{l}\text { Flask- } \\
\text { shaped, } \\
300-550 \times \\
250-300\end{array}$ & $\begin{array}{l}152- \\
280 \\
\times 6- \\
10\end{array}$ & $\begin{array}{l}4 \\
\mu \mathrm{m} \\
\text { thick }\end{array}$ & $\begin{array}{l}11-16 \\
\times 1.5- \\
2.5\end{array}$ & $\begin{array}{l}\text { Mongkolsamrit } \\
\text { et al. (2015) }\end{array}$ \\
\hline M. basicystis & $\begin{array}{l}\text { Caribbean } \\
\text { Islands, } \\
\text { Costa Rica, } \\
\text { Cuba, } \\
\text { Panama, } \\
\text { Southern } \\
\text { Central } \\
\text { America }\end{array}$ & $\begin{array}{l}\text { Scale } \\
\text { insects, } \\
\text { whiteflies }\end{array}$ & $\begin{array}{l}1-2 \mathrm{~mm} \\
\text { diam }\end{array}$ & $\begin{array}{l}\text { Flask- } \\
\text { shaped, } \\
300-450 \times \\
160-250\end{array}$ & $\begin{array}{l}190- \\
298 \\
\times \\
9.3- \\
18\end{array}$ & $\begin{array}{l}3.2- \\
5.3 \\
\mu \mathrm{m} \\
\text { thick }\end{array}$ & $\begin{array}{l}11.5- \\
26 \times \\
2.7- \\
4.5\end{array}$ & $\begin{array}{l}\text { Chaverri et al. } \\
(2008)\end{array}$ \\
\hline M. boliviensis & $\begin{array}{l}\text { Bolivia, } \\
\text { Brazil }\end{array}$ & Whiteflies & $\begin{array}{l}0.8-3 \\
\mathrm{~mm} \\
\text { diam }\end{array}$ & $\begin{array}{l}\text { Subglobose } \\
\text { to ovoid, } \\
300-400 \times \\
250-300\end{array}$ & $\begin{array}{l}134- \\
150 \\
\times 8- \\
8.5\end{array}$ & $\begin{array}{l}0.8- \\
1.7 \\
\mu \mathrm{m} \\
\text { thick }\end{array}$ & $\begin{array}{l}4.5- \\
7.5 \times \\
2-2.5\end{array}$ & $\begin{array}{l}\text { Chaverri et al. } \\
(2008)\end{array}$ \\
\hline M. castanea & Trinidad & $\begin{array}{l}\text { Scale } \\
\text { insects }\end{array}$ & $\begin{array}{l}1-2 \mathrm{~mm} \\
\text { diam }\end{array}$ & $\begin{array}{l}\text { Flask- } \\
\text { shaped, } \\
200-250 \times \\
110-130\end{array}$ & - & - & $\begin{array}{l}4.5^{-} \\
6.3^{x} \\
1.5^{-} \\
2.2\end{array}$ & $\begin{array}{l}\text { Chaverri et al. } \\
(2008)\end{array}$ \\
\hline $\begin{array}{l}\text { M. } \\
\text { chiangmaiensis }\end{array}$ & Thailand & $\begin{array}{l}\text { Scale } \\
\text { insects }\end{array}$ & $\begin{array}{l}4-7 \mathrm{~mm} \\
\text { diam }\end{array}$ & $\begin{array}{l}\text { Obpyriform, } \\
450-500 \times \\
260-360\end{array}$ & $\begin{array}{l}102- \\
220 \\
\times 4-7\end{array}$ & $\begin{array}{l}4 \\
\text { thick }\end{array}$ & $\begin{array}{l}7-12 \times \\
1-2\end{array}$ & This study \\
\hline $\begin{array}{l}\text { M. } \\
\text { chumphonensis }\end{array}$ & Thailand & $\begin{array}{l}\text { Scale } \\
\text { insects, } \\
\text { whiteflies }\end{array}$ & $\begin{array}{l}2-8 \times 0.5- \\
0.8\end{array}$ & $\begin{array}{l}\text { Flask- } \\
\text { shaped, } \\
580-600 \times \\
340-400\end{array}$ & $\begin{array}{l}290- \\
380 \\
\times 14- \\
16\end{array}$ & $\begin{array}{l}5-7 \\
\mu m \\
\text { thick }\end{array}$ & $\begin{array}{l}6-12.5 \\
\times 1.5- \\
4\end{array}$ & $\begin{array}{l}\text { Mongkolsamrit } \\
\text { et al. (2015) }\end{array}$ \\
\hline M. colliculosa & Brazil & $\begin{array}{l}\text { Scale } \\
\text { insects, } \\
\text { whiteflies }\end{array}$ & $\begin{array}{l}1.5-2 \\
\mathrm{~mm} \\
\text { diam }\end{array}$ & $\begin{array}{l}\text { Flask- } \\
\text { shaped, } \\
\text { subglobose, } \\
250-300 \times \\
150\end{array}$ & & $\begin{array}{l}1.5^{-} \\
2 \\
\mu \mathrm{m} \\
\text { thick }\end{array}$ & $\begin{array}{l}10.2- \\
13.7 \times \\
3.5-5\end{array}$ & $\begin{array}{l}\text { Chaverri et al. } \\
(2008)\end{array}$ \\
\hline M. cornuta & Brazil & $\begin{array}{l}\text { Scale } \\
\text { insects, } \\
\text { whiteflies }\end{array}$ & $1-3 \times 2-9$ & $\begin{array}{l}\text { Flask- } \\
\text { shaped, } \\
275-430 \times \\
135-180\end{array}$ & $\begin{array}{l}175- \\
196 \\
\times \\
8.5- \\
12.2\end{array}$ & $\begin{array}{l}4.5^{-} \\
6 \\
\mu \mathrm{m} \\
\text { thick }\end{array}$ & $\begin{array}{l}7.8- \\
10.5 \times \\
2-2.5\end{array}$ & $\begin{array}{l}\text { Chaverri et al. } \\
(2008)\end{array}$ \\
\hline M. disjuncta & $\begin{array}{l}\text { French } \\
\text { Guiana, } \\
\text { Guyana, } \\
\text { Panama, } \\
\text { Puerto Rico, } \\
\text { Trinidad }\end{array}$ & $\begin{array}{l}\text { Scale } \\
\text { insects, } \\
\text { whiteflies }\end{array}$ & $\begin{array}{l}1-3 \times 0.5- \\
1.5\end{array}$ & $\begin{array}{l}\text { Flask- } \\
\text { shaped, } \\
350-400 \times \\
200-250\end{array}$ & $\begin{array}{l}145- \\
231 \\
\times \\
9.5- \\
18.3\end{array}$ & $\begin{array}{l}1.8- \\
3.3 \\
\mu m \\
\text { thick }\end{array}$ & $\begin{array}{l}6.8- \\
11.5 \times \\
2.5^{-} \\
3.5\end{array}$ & $\begin{array}{l}\text { Chaverri et al. } \\
(2008)\end{array}$ \\
\hline M. epiphylla & $\begin{array}{l}\text { Bolivia, } \\
\text { Colombia, } \\
\text { Costa Rica, } \\
\text { Cuba, } \\
\text { Ecuador, } \\
\text { Guyana, } \\
\text { Honduras, } \\
\text { Mexico, } \\
\text { Saint } \\
\text { Vincent }\end{array}$ & $\begin{array}{l}\text { Scale } \\
\text { insects, } \\
\text { whiteflies }\end{array}$ & $\begin{array}{l}0.8-3 \\
\mathrm{~mm} \\
\text { diam }\end{array}$ & $\begin{array}{l}\text { Flask- } \\
\text { shaped, } \\
400-550 \times \\
200\end{array}$ & - & - & $\begin{array}{l}7.8-12 \\
\times 3.5- \\
4.5\end{array}$ & $\begin{array}{l}\text { Chaverri et al. } \\
(2008)\end{array}$ \\
\hline M. evansii & Ecuador & Scale & $7-10$ mm & Subglobose & $121-$ & 4.5 & $6-17.2$ & Chaverri et al. \\
\hline
\end{tabular}




\begin{tabular}{|c|c|c|c|c|c|c|c|c|}
\hline & & $\begin{array}{l}\text { insects, } \\
\text { whiteflies }\end{array}$ & diam & $\begin{array}{l}\text { to ovoid, } \\
300-400 \times \\
350-500\end{array}$ & $\begin{array}{l}325 \\
\times \\
8.5- \\
13.7\end{array}$ & $\begin{array}{l}\mu \mathrm{m} \\
\text { thick }\end{array}$ & $\begin{array}{l}\times 1.8- \\
4.2\end{array}$ & (2008) \\
\hline M. flava & Thailand & $\begin{array}{l}\text { Scale } \\
\text { insects }\end{array}$ & $\begin{array}{l}2.5-4.5 \\
\mathrm{~mm} \\
\text { diam }\end{array}$ & $\begin{array}{l}\text { Obpyriform, } \\
260-430 \times \\
90-170\end{array}$ & $\begin{array}{l}138- \\
250 \\
\times 5-7\end{array}$ & $\begin{array}{l}4-7 \\
\mu m \\
\text { thick }\end{array}$ & $\begin{array}{l}6-11 \times \\
1-1.5\end{array}$ & This study \\
\hline M. gaertneriana & $\begin{array}{l}\text { Brazil, } \\
\text { French } \\
\text { Guiana, } \\
\text { Venezuela. }\end{array}$ & $\begin{array}{l}\text { Scale } \\
\text { insects }\end{array}$ & $\begin{array}{l}6-30 \times 6- \\
20\end{array}$ & $\begin{array}{l}\text { Flask- } \\
\text { shaped, } \\
247-378 \times \\
142-378\end{array}$ & $\begin{array}{l}120- \\
178 \\
\times 4- \\
6.5\end{array}$ & $\begin{array}{l}3.3- \\
4 \\
\mu \mathrm{m} \\
\text { thick }\end{array}$ & $\begin{array}{l}4-8 \times \\
1.5-2\end{array}$ & $\begin{array}{l}\text { Chaverri et al. } \\
\text { (2008) }\end{array}$ \\
\hline M. globosa & $\begin{array}{l}\text { Brazil, } \\
\text { Trinidad }\end{array}$ & $\begin{array}{l}\text { Scale } \\
\text { insects, } \\
\text { whiteflies }\end{array}$ & $\begin{array}{l}1-5.5 \\
\text { mm } \\
\text { diam }\end{array}$ & $\begin{array}{l}\text { Flask- } \\
\text { shaped, } \\
300-400 \times \\
200-250\end{array}$ & $\begin{array}{l}150- \\
160 \\
\times 8- \\
10\end{array}$ & - & $\begin{array}{r}6.5-9 \\
\times 2-3\end{array}$ & $\begin{array}{l}\text { Chaverri et al. } \\
\text { (2008) }\end{array}$ \\
\hline M. guaranitica & $\begin{array}{l}\text { Brazil, } \\
\text { Paraguay }\end{array}$ & Insects & $\begin{array}{l}1-4 \mathrm{~mm} \\
\text { diam }\end{array}$ & $\begin{array}{l}\text { Flask- } \\
\text { shaped, } \\
400-450 \times \\
200-250\end{array}$ & $\begin{array}{l}150- \\
200 \\
\times \\
7.5- \\
10\end{array}$ & - & $\begin{array}{l}5.5- \\
8.2 \times \\
2-3\end{array}$ & $\begin{array}{l}\text { Chaverri et al. } \\
\text { (2008) }\end{array}$ \\
\hline M. libera & Neotropical & $\begin{array}{l}\text { Scale } \\
\text { insects, } \\
\text { whiteflies }\end{array}$ & $\begin{array}{l}0.7-2 \\
\mathrm{~mm} \\
\text { diam }\end{array}$ & $\begin{array}{l}\text { Globose to } \\
\text { ovoid, 300- } \\
400 \times 300- \\
600\end{array}$ & $\begin{array}{l}5 \\
\mu \text { mick }\end{array}$ & - & $\begin{array}{l}13-16 \\
\times 2.5- \\
3\end{array}$ & $\begin{array}{l}\text { Chaverri et al. } \\
\text { (2008) }\end{array}$ \\
\hline $\begin{array}{l}\text { M. } \\
\text { macrostroma }\end{array}$ & Bolivia & $\begin{array}{l}\text { Scale } \\
\text { insects, } \\
\text { whiteflies }\end{array}$ & $\begin{array}{l}\text { 3-22 mm } \\
\text { diam }\end{array}$ & $\begin{array}{l}\text { Obpyriform, } \\
377-451 \times \\
137-152\end{array}$ & $\begin{array}{l}140- \\
197 \\
\times \\
5.2-7\end{array}$ & $\begin{array}{l}3-4 \\
\mu m \\
\text { thick }\end{array}$ & $\begin{array}{l}8.7-18 \\
\times 2.2- \\
3\end{array}$ & $\begin{array}{l}\text { Chaverri et al. } \\
(2005 b)\end{array}$ \\
\hline M. mollii & Indonesia & $\begin{array}{l}\text { Whitefly } \\
\text { (Aleyrodes } \\
\text { sp.) }\end{array}$ & $\begin{array}{l}2-4 \mathrm{~mm} \\
\text { diam }\end{array}$ & $\begin{array}{l}\text { Flask- } \\
\text { shaped, } \\
\leq 500 \times \\
\leq 200\end{array}$ & $\begin{array}{l}170- \\
180 \\
\times 6-8\end{array}$ & - & $\begin{array}{l}8-17 x \\
1.5-2\end{array}$ & $\begin{array}{l}\text { Koorders } \\
(1907), \text { Petch } \\
(1921)\end{array}$ \\
\hline M. nanensis & Thailand & $\begin{array}{l}\text { Scale } \\
\text { insects }\end{array}$ & $\begin{array}{l}3-6 \mathrm{~mm} \\
\text { diam }\end{array}$ & $\begin{array}{l}\text { Obpyriform, } \\
310-550 \times \\
110-180\end{array}$ & $\begin{array}{l}105- \\
238 \\
\times 5- \\
12\end{array}$ & $\begin{array}{l}3.5- \\
6 \\
\mu m \\
\text { thick }\end{array}$ & $\begin{array}{l}7-18 \times \\
1-2\end{array}$ & This study \\
\hline M. nivea & Thailand & $\begin{array}{l}\text { Scale } \\
\text { insects }\end{array}$ & $\begin{array}{l}3-3.5 \\
\text { mm } \\
\text { diam }\end{array}$ & $\begin{array}{l}\text { Obpyriform, } \\
260-420 \times \\
110-230\end{array}$ & $\begin{array}{l}130- \\
185 \\
\times 5-7\end{array}$ & $\begin{array}{l}5-7 \\
\mu m \\
\text { thick }\end{array}$ & $\begin{array}{r}5-0.5 \\
\times 1-2\end{array}$ & This study \\
\hline M. ochracea & Neotropical & $\begin{array}{l}\text { Scale } \\
\text { insects, } \\
\text { whiteflies }\end{array}$ & $\begin{array}{l}1-3 \mathrm{~mm} \\
\text { diam }\end{array}$ & $\begin{array}{l}\text { Flask- } \\
\text { shaped, } \\
250-450 \times \\
160-300\end{array}$ & $\begin{array}{l}138- \\
180 \\
\times 5-8\end{array}$ & $\begin{array}{l}3- \\
3.5 \\
\mu m \\
\text { thick }\end{array}$ & $\begin{array}{l}12-15 \\
\times 1.5- \\
2\end{array}$ & $\begin{array}{l}\text { Chaverri et al. } \\
\text { (2008) }\end{array}$ \\
\hline M. palmae & $\begin{array}{l}\text { Brazil, Peru, } \\
\text { Surinam }\end{array}$ & $\begin{array}{l}\text { Scale } \\
\text { insects, } \\
\text { whiteflies }\end{array}$ & $\begin{array}{l}0.6-6.5 \\
\mathrm{~mm} \\
\text { diam }\end{array}$ & $\begin{array}{l}\text { Flask- } \\
\text { shaped, } \\
400-450 \times \\
200-250\end{array}$ & $\begin{array}{l}160- \\
200 \\
\times 7- \\
9.5\end{array}$ & $\begin{array}{l}1 \\
\mu \mathrm{m} \\
\text { thick }\end{array}$ & $\begin{array}{l}8-11.2 \\
\times 2.2- \\
3\end{array}$ & $\begin{array}{l}\text { Chaverri et al. } \\
\text { (2008) }\end{array}$ \\
\hline $\begin{array}{l}\text { M. } \\
\text { phukhiaoensis }\end{array}$ & Thailand & $\begin{array}{l}\text { Scale } \\
\text { insects }\end{array}$ & $\begin{array}{l}\leq 5 \mathrm{~mm} \\
\text { diam }\end{array}$ & $\begin{array}{l}\text { Flask- } \\
\text { shaped, } \\
400-520 \times \\
150-200\end{array}$ & $\begin{array}{l}195- \\
220 \\
\times 8- \\
12\end{array}$ & $\begin{array}{l}4-6 \\
\mu m \\
\text { thick }\end{array}$ & $\begin{array}{l}12.5- \\
17.5 \times \\
2-3\end{array}$ & Li et al. (2016) \\
\hline M. phyllogena & $\begin{array}{l}\text { Argentina, } \\
\text { Bolivia, } \\
\text { Brazil, } \\
\text { Colombia, } \\
\text { Ecuador, } \\
\text { French }\end{array}$ & $\begin{array}{l}\text { Scale } \\
\text { insects, } \\
\text { whiteflies }\end{array}$ & $\begin{array}{l}1-3 \mathrm{~mm} \\
\text { diam }\end{array}$ & 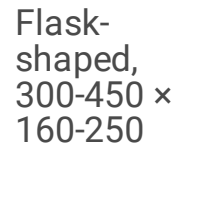 & $\begin{array}{l}190- \\
300 \\
\times \\
9.5- \\
21.5\end{array}$ & $\begin{array}{l}2- \\
6.5 \\
\mu m \\
\text { thick }\end{array}$ & $\begin{array}{l}13.7- \\
25 \times \\
2.5- \\
4.5\end{array}$ & $\begin{array}{l}\text { Chaverri et al. } \\
\text { (2008) }\end{array}$ \\
\hline
\end{tabular}




\begin{tabular}{|c|c|c|c|c|c|c|c|c|}
\hline & $\begin{array}{l}\text { Guiana, } \\
\text { Panama, } \\
\text { Peru, } \\
\text { Venezuela }\end{array}$ & & & & & & & \\
\hline M. rhombispora & $\begin{array}{l}\text { Costa Rica, } \\
\text { Guatemala, } \\
\text { Honduras, } \\
\text { Mexico, } \\
\text { Puerto Rico. }\end{array}$ & $\begin{array}{l}\text { Scale } \\
\text { insects, } \\
\text { whiteflies }\end{array}$ & $\begin{array}{l}2-2.5 \\
\mathrm{~mm} \\
\text { diam }\end{array}$ & $\begin{array}{l}300-450 \times \\
210-300\end{array}$ & $\begin{array}{l}148- \\
296 \\
\times 6- \\
14\end{array}$ & $\begin{array}{l}5-8 \\
\mu m \\
\text { thick }\end{array}$ & $\begin{array}{l}10-14 \\
\times 2-3\end{array}$ & $\begin{array}{l}\text { Chaverri et al. } \\
(2008)\end{array}$ \\
\hline M. sinensis & Thailand & $\begin{array}{l}\text { Scale } \\
\text { insects }\end{array}$ & $\begin{array}{l}2-6 \mathrm{~mm} \\
\text { diam }\end{array}$ & $\begin{array}{l}\text { Obpyriform, } \\
270-480 \times \\
130-260\end{array}$ & $\begin{array}{l}161- \\
238 \\
\times 6- \\
11\end{array}$ & $\begin{array}{l}4- \\
6.5 \\
\mu \mathrm{m} \\
\text { thick }\end{array}$ & $\begin{array}{l}7-26 \times \\
1-2\end{array}$ & This study \\
\hline M. sloaneae & $\begin{array}{l}\text { Belize, } \\
\text { Bolivia, } \\
\text { Brazil, } \\
\text { Ecuador, } \\
\text { Guadeloupe, } \\
\text { Guatemala, } \\
\text { Guyana, } \\
\text { Honduras, } \\
\text { Peru, } \\
\text { Venezuela }\end{array}$ & $\begin{array}{l}\text { Scale } \\
\text { insects, } \\
\text { whiteflies }\end{array}$ & $\begin{array}{l}1.5-2.2 \\
\mathrm{~mm} \\
\text { diam }\end{array}$ & $\begin{array}{l}\text { Flask- } \\
\text { shaped, } \\
400-500 \times \\
250-300\end{array}$ & $\begin{array}{l}163- \\
248 \\
\times \\
7.2- \\
10.5\end{array}$ & $\begin{array}{l}3.3- \\
6.3 \\
\mu \mathrm{m} \\
\text { thick }\end{array}$ & $\begin{array}{l}9-18.3 \\
\times 2-4\end{array}$ & $\begin{array}{l}\text { Chaverri et al. } \\
(2008)\end{array}$ \\
\hline M. turbinata & Neotropics & $\begin{array}{l}\text { Scale } \\
\text { insects, } \\
\text { whiteflies }\end{array}$ & $\begin{array}{l}1-5 \mathrm{~mm} \\
\text { diam }\end{array}$ & $\begin{array}{l}\text { Flask- } \\
\text { shaped to } \\
\text { Obpyriform, } \\
264-320 \times \\
116-130\end{array}$ & $\begin{array}{l}210- \\
275 \\
\times 8- \\
14\end{array}$ & $\begin{array}{l}2.8- \\
4.5 \\
\mu \mathrm{m} \\
\text { thick }\end{array}$ & $\begin{array}{l}13-21 \\
\times 2.8- \\
4.2\end{array}$ & $\begin{array}{l}\text { Chaverri et al. } \\
(2008)\end{array}$ \\
\hline M. umbospora & $\begin{array}{l}\text { Honduras, } \\
\text { Mexico }\end{array}$ & $\begin{array}{l}\text { Scale } \\
\text { insects, } \\
\text { whiteflies }\end{array}$ & $\begin{array}{l}0.5-2.5 \\
\mathrm{~mm} \\
\text { diam }\end{array}$ & $\begin{array}{l}\text { Flask- } \\
\text { shaped, } \\
375-500 \times \\
200-280\end{array}$ & $\begin{array}{l}274- \\
340 \\
\times \\
21.2- \\
31.5\end{array}$ & $\begin{array}{l}3-4 \\
\mu m \\
\text { thick }\end{array}$ & $\begin{array}{l}21.5- \\
30.1 \times \\
4-5.5\end{array}$ & $\begin{array}{l}\text { Chaverri et al. } \\
(2008)\end{array}$ \\
\hline M. zhongdongii & $\begin{array}{l}\text { Bolivia, } \\
\text { Costa Rica, } \\
\text { Puerto Rico. }\end{array}$ & $\begin{array}{l}\text { Scale } \\
\text { insects, } \\
\text { whiteflies }\end{array}$ & & $\begin{array}{l}\text { Flask- } \\
\text { shaped, } \\
350-450 \times \\
125-200\end{array}$ & $\begin{array}{l}300 \\
\times 6- \\
10\end{array}$ & $\begin{array}{l}4-5 \\
\mu m \\
\text { thick }\end{array}$ & $\begin{array}{l}5-10 \times \\
1-2\end{array}$ & $\begin{array}{l}\text { Liu and Hodge } \\
\text { (2008) }\end{array}$ \\
\hline
\end{tabular}

\section{Figures}




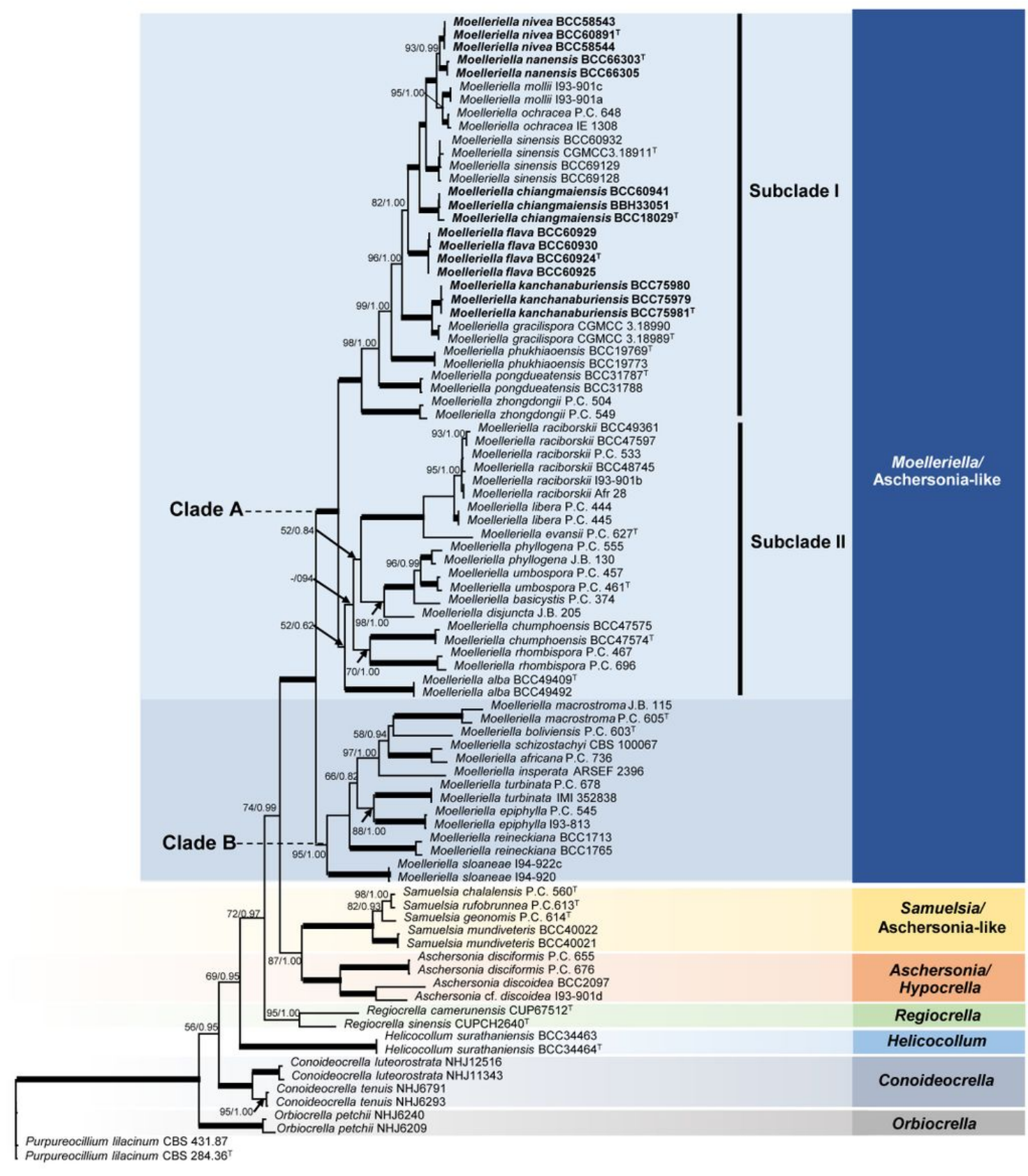

\section{Figure 1}

Phylogenetic relationships of Moelleriella (Clavicipitaceae) from a multigene dataset (LSU, TEF and RPB1) based on maximum likelihood (RAXML) and Bayesian inference. Numbers along branches are ML bootstrap values and bayesian posterior probabilities (bold branches show strong support, 99-100\%) 

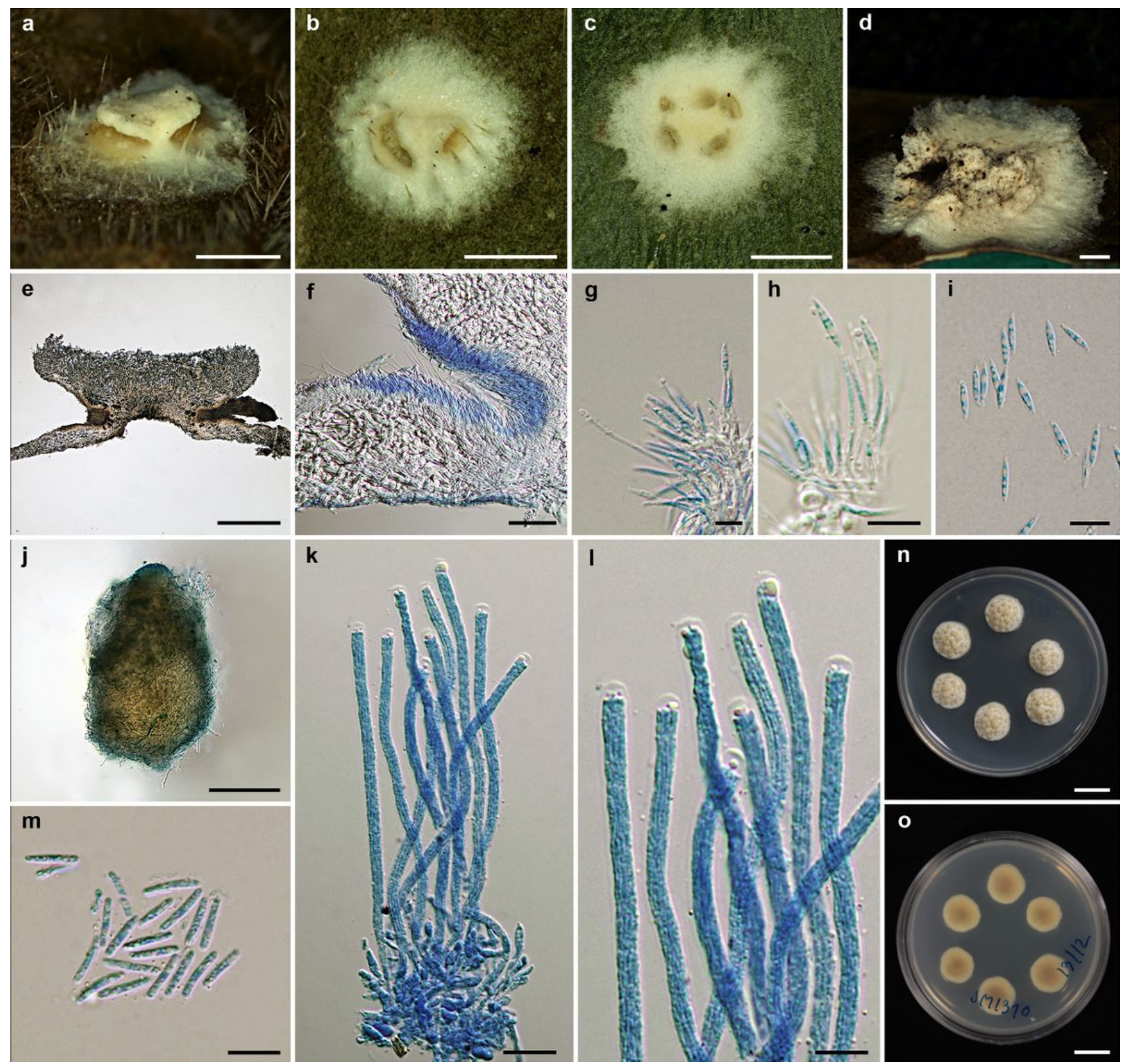

\section{Figure 2}

Moelleriella chiangmaiensis. a-c Anamorphic stroma containing conidiomata. d Telemorphic stroma containing conidiomata and perithecia. e-f Section of stroma showing conidiomata. g Phialide and conidium at the tips with papaphyses. $\mathrm{h}$ Phialide with conidia at the tips. i Conidia. j Perithecium. k-I. Asci and caps. $\mathrm{m}$ Part-spores. $\mathrm{n}$ Colony obverse on PDA at $25^{\circ} \mathrm{C}$ after 2 wk. o. Colony reverse on PDA at $25^{\circ} \mathrm{C}$ after 2 wk. Scale bars: $\mathrm{n}, \mathrm{o}=10 \mathrm{~mm}$; a-d $=1 \mathrm{~mm}$. e = $500 \mu \mathrm{m}$. $j=200 \mu \mathrm{m} . \mathrm{f}=100 \mu \mathrm{m} . \mathrm{k}=20 \mu \mathrm{m} . \mathrm{g}-\mathrm{i}, \mathrm{l}, \mathrm{m}=20 \mu \mathrm{m}$. 

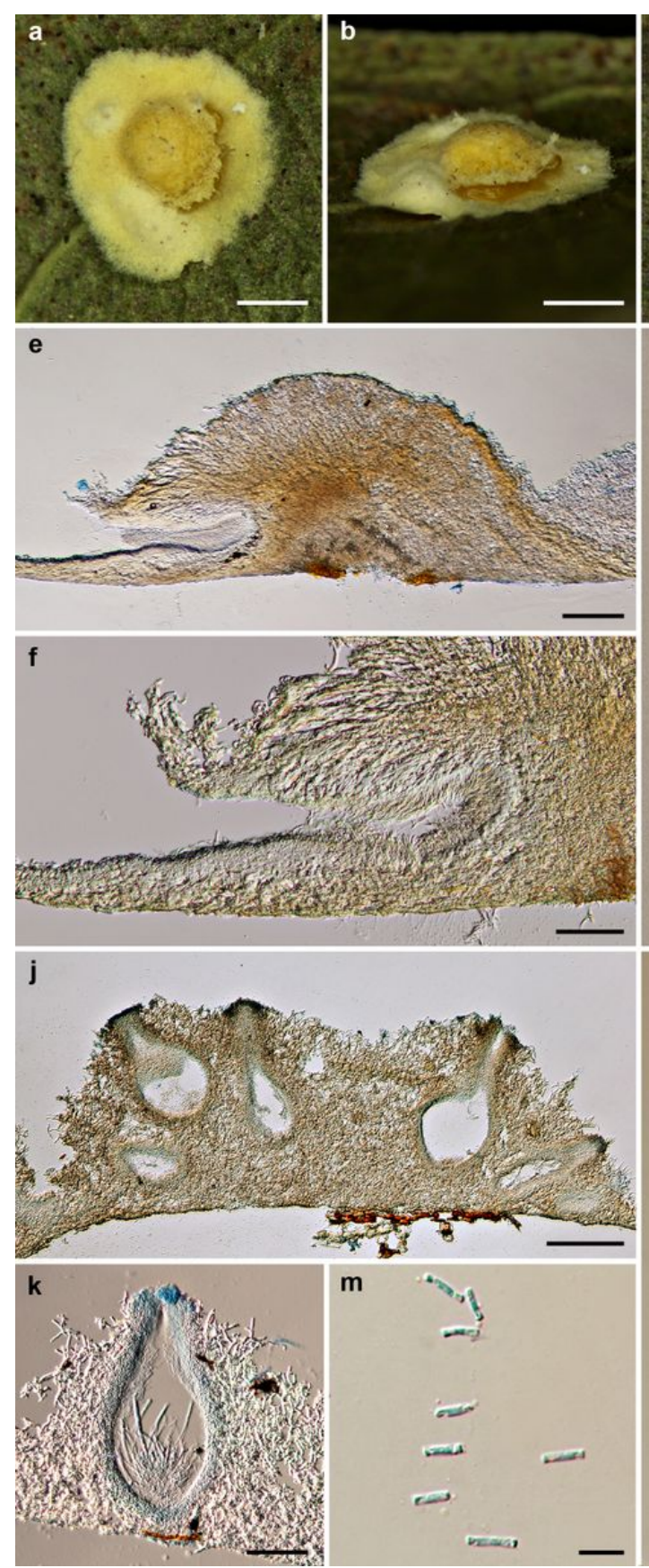
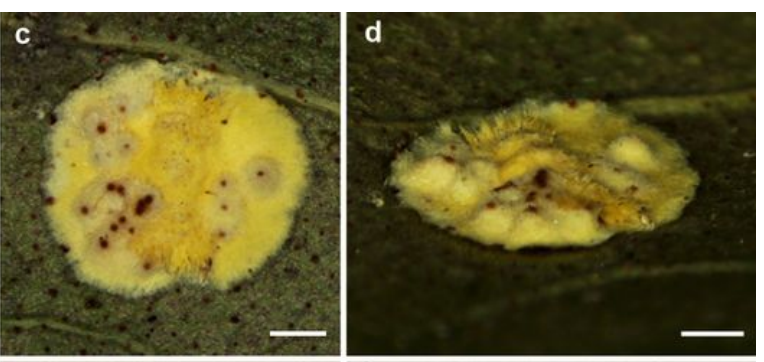

g
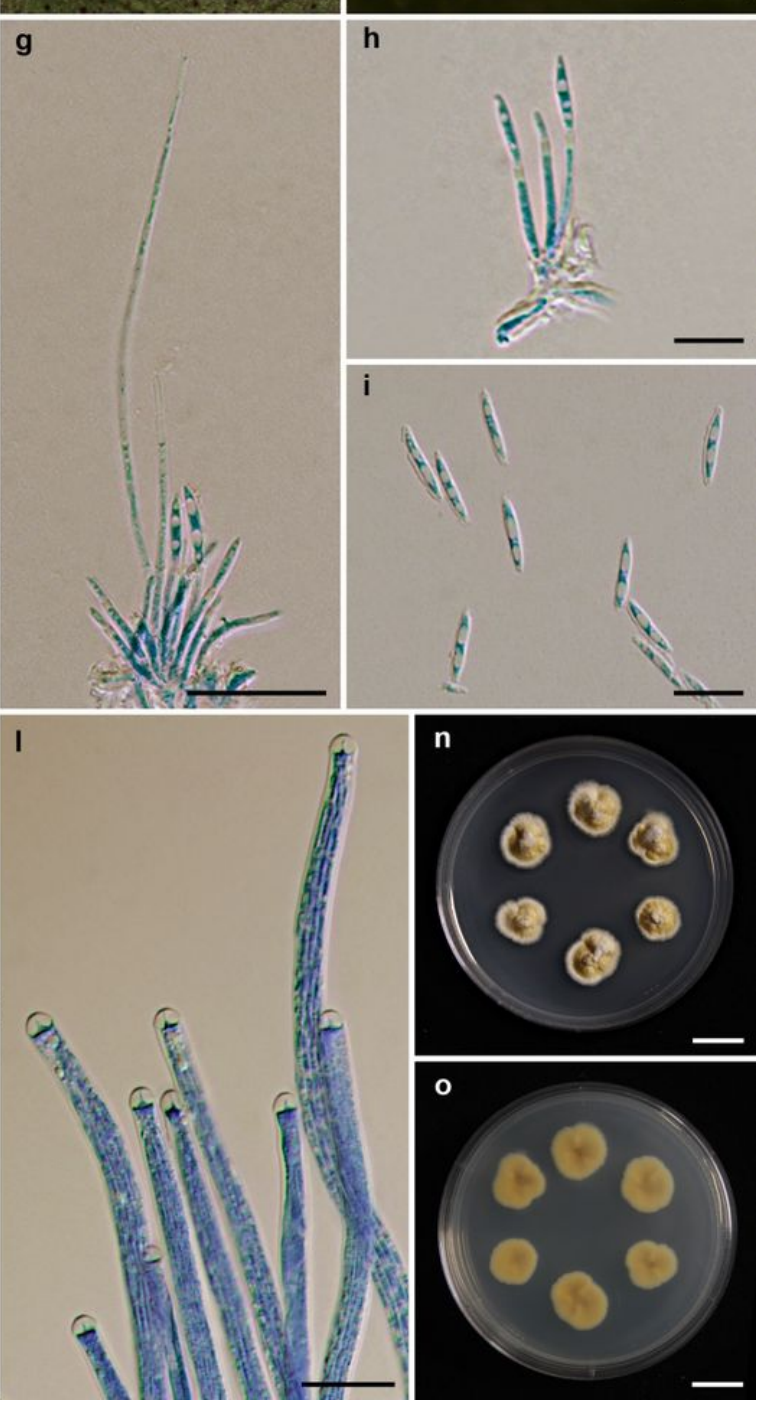

Figure 3

Moelleriella flava. a, b Anamorphic stroma. c, d Telemorphic stroma. e, f Section of stroma showing conidioma. g Phialide and conidia at the tips with papaphyses. h Phialide with conidia at the tips. i Conidia. j Section of stroma showing perithecia. k Perithecium. I Asci and caps. m Part-spores. n Colony obverse on PDA at $25^{\circ} \mathrm{C}$ after 2 wk. o Colony reverse on PDA at $25^{\circ} \mathrm{C}$ after 2 wk. Scale bars: $n, o=10 \mathrm{~mm}$. $a-d=1 \mathrm{~mm} . \mathrm{e}, \mathrm{j}=200 \mu \mathrm{m} . \mathrm{f}, \mathrm{k}=100 \mu \mathrm{m} . \mathrm{g}, \mathrm{I}=20 \mu \mathrm{m} . \mathrm{h}, \mathrm{i}, \mathrm{m}=10 \mu \mathrm{m}$. 

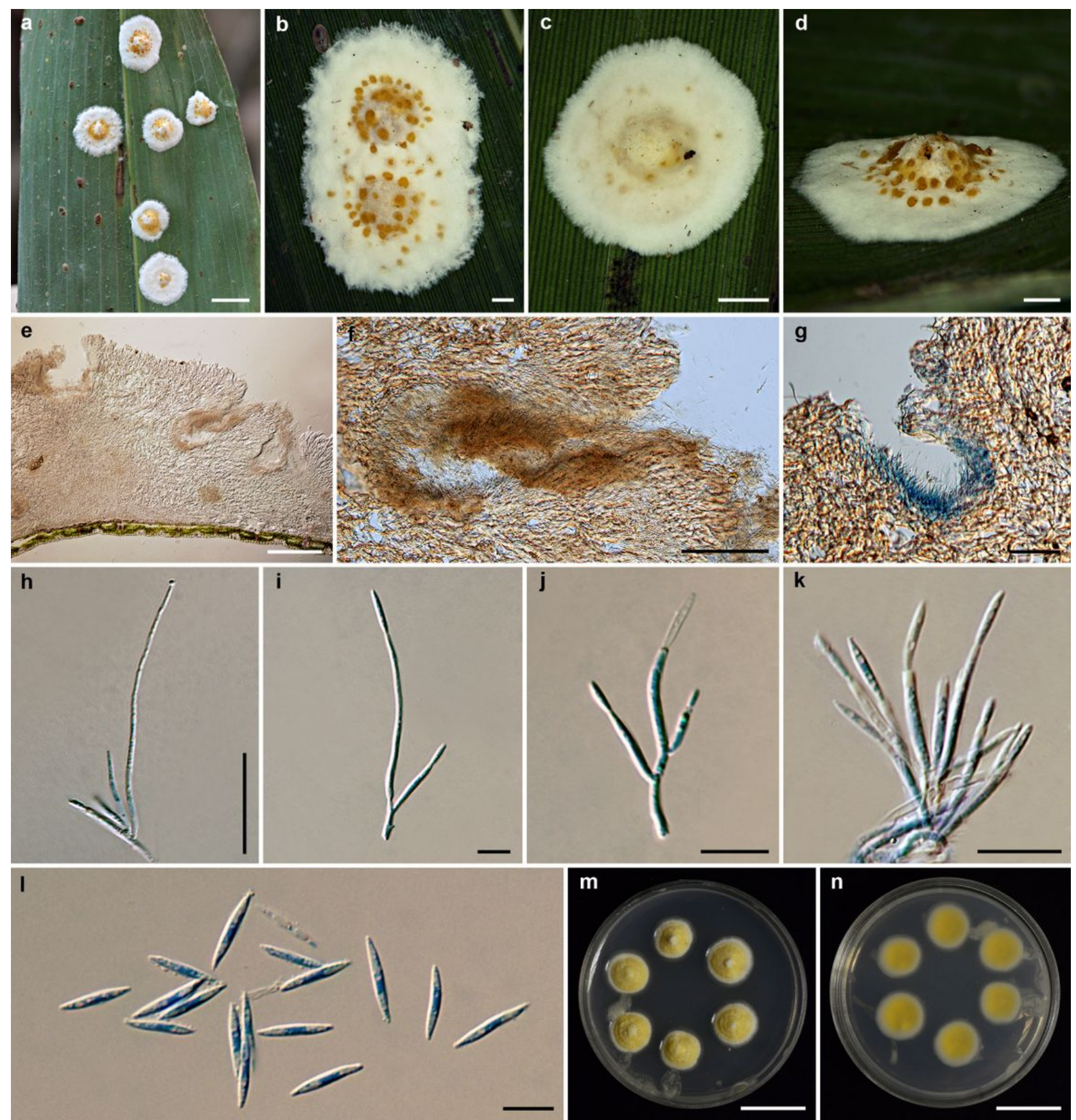

Figure 4

Moelleriella kanchanaburiensis. a-d Anamorphic stromata containing conidiomata with conidial masses. e-g Section of stroma showing conidiomata. h Phialide and conidium at the tips with papaphyses. i-k. Phialide and conidia at the tips. I Conidia. $\mathrm{m}$ Colony obverse on PDA at $25^{\circ} \mathrm{C}$ after $2 \mathrm{wk}$. $\mathrm{n}$ Colony reverse on PDA at $25^{\circ} \mathrm{C}$ after 2 wk. Scale bars: $\mathrm{m}, \mathrm{n},=10$ $\mathrm{mm} . \mathrm{a}=5 \mathrm{~mm}$. b-d = $1 \mathrm{~mm} . \mathrm{e}=200 \mu \mathrm{m} . \mathrm{f}, \mathrm{g}=100 \mu \mathrm{m} . \mathrm{h}=20 \mu \mathrm{m} . \mathrm{i}-\mathrm{I}=10 \mu \mathrm{m}$. 

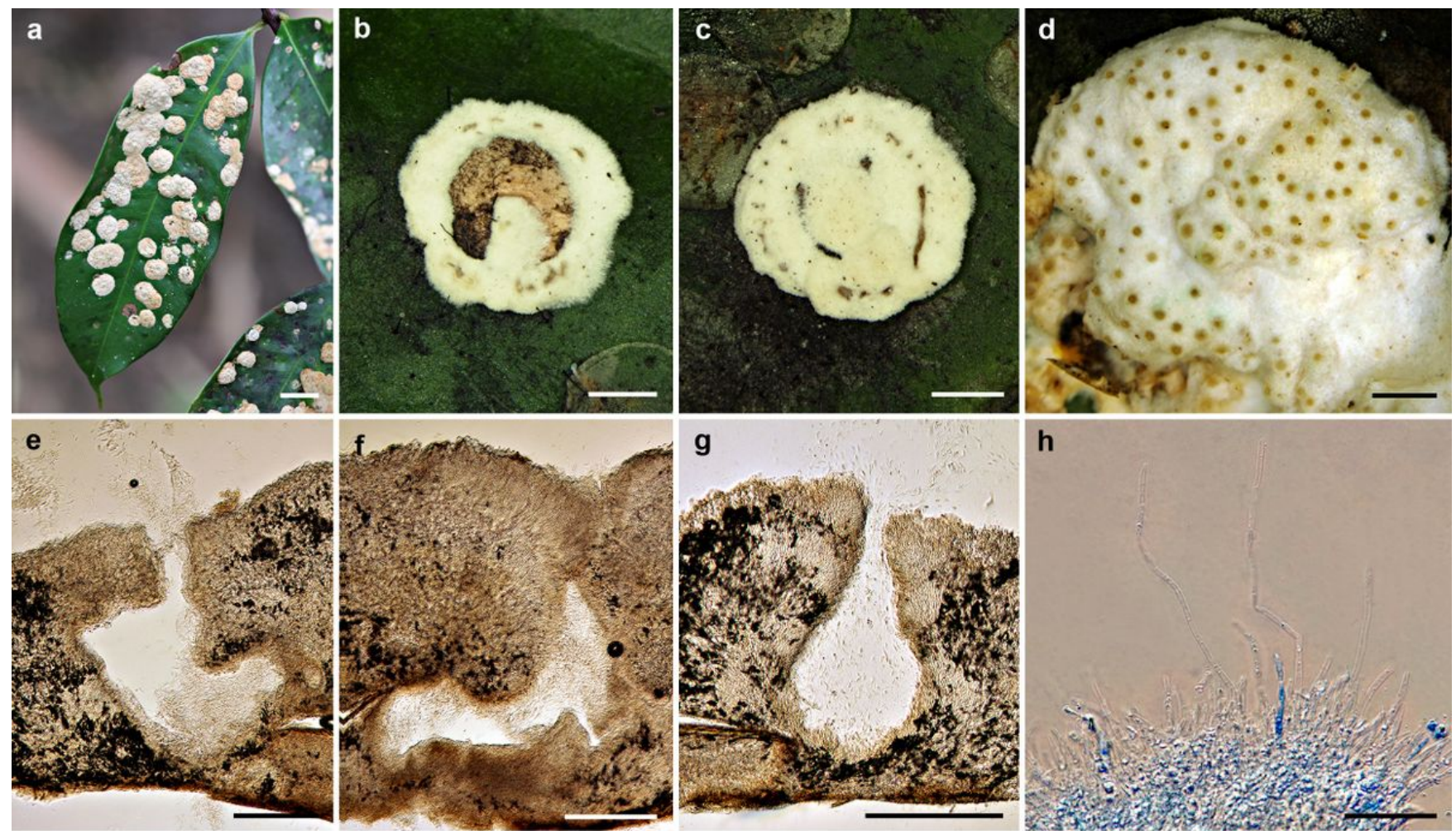

h
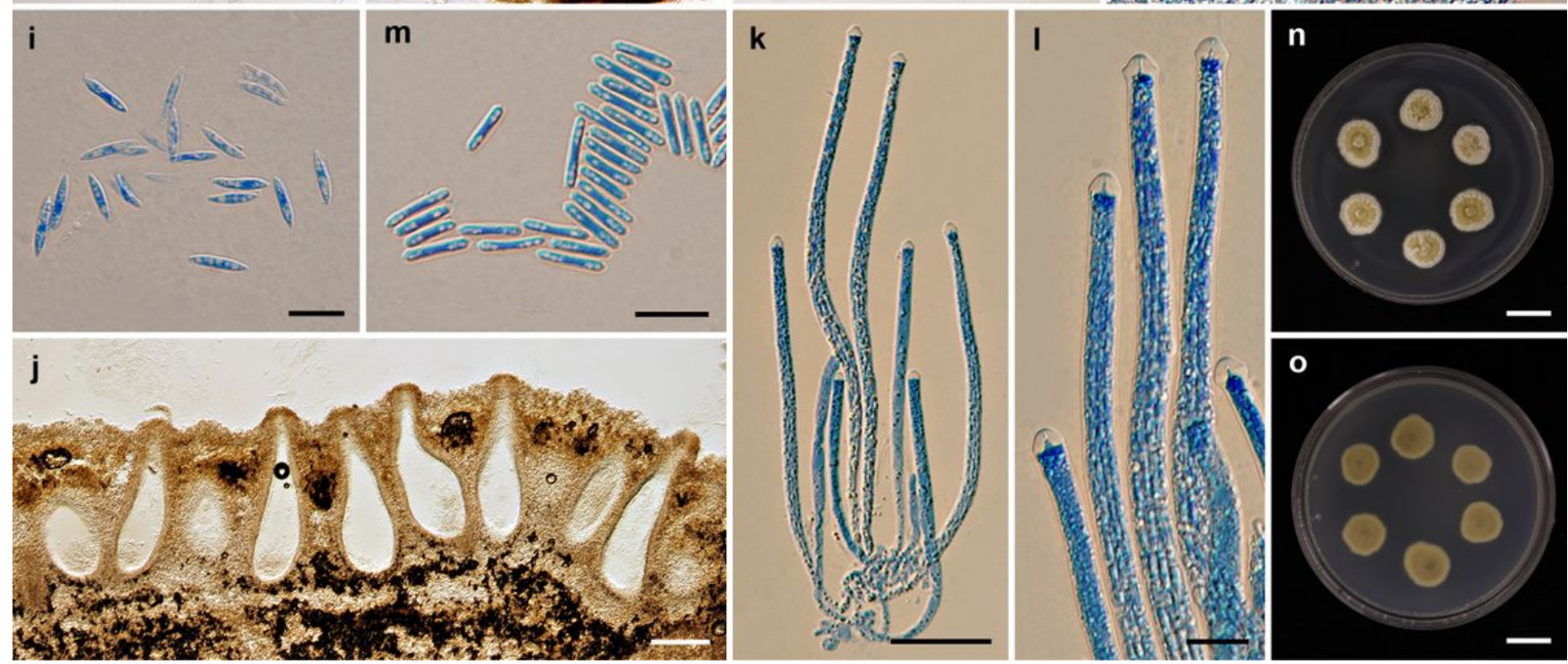

Figure 5

Moelleriella nanensis. a Stromata on upper side of dicotyledonous leaves. b-c Anamorphic stroma containing conidiomata. d Telemorphic stroma. e-g. Section of stroma showing conidioma. h Phialide and conidium at the tips with papaphyses. i conidia. j Perithecia. k Mature asci and developing asci. I Asci and caps. m Part-spores. $n$ Colony obverse on PDA at $25^{\circ} \mathrm{C}$ after 3 wk. $n$ Colony reverse on PDA at $25^{\circ} \mathrm{C}$ after 3 wk. Scale bars: $a, n, o=10 \mathrm{~mm}$. b-d $=1 \mathrm{~mm} . \mathrm{e}-\mathrm{g}, \mathrm{j}=200 \mu \mathrm{m} . \mathrm{k}=50 \mu \mathrm{m}$. $\mathrm{h}=20 \mu \mathrm{m}$. i, l, $\mathrm{m}=10 \mu \mathrm{m}$. 

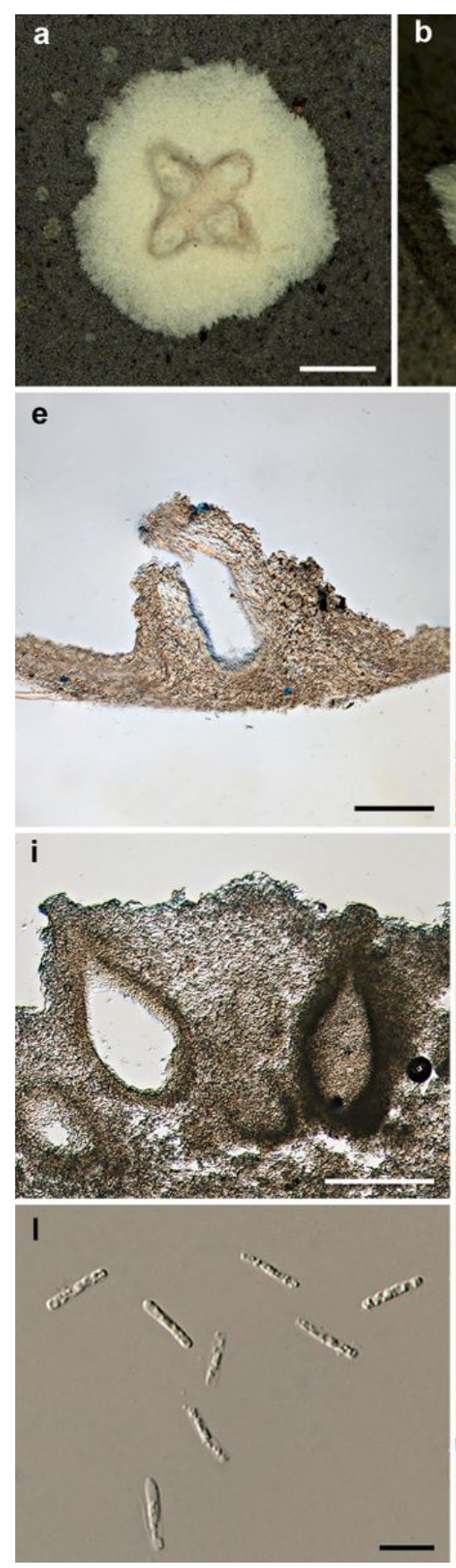
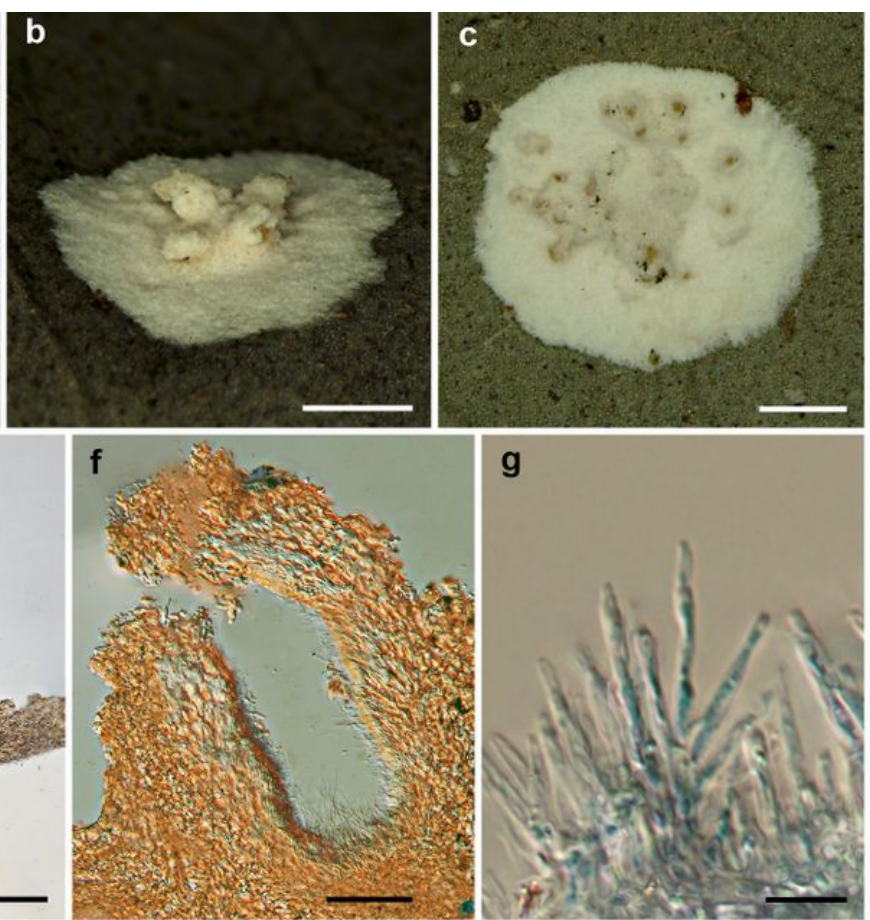

g

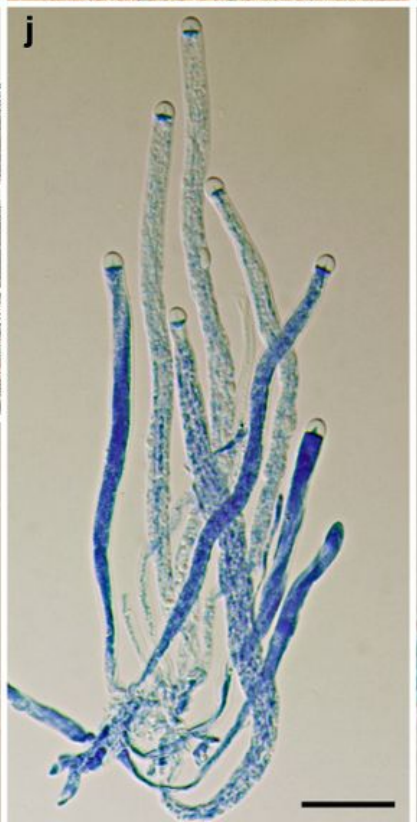

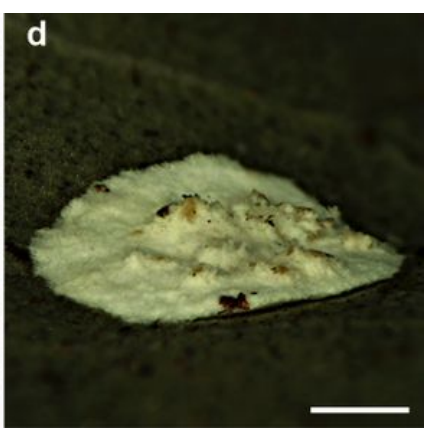

h
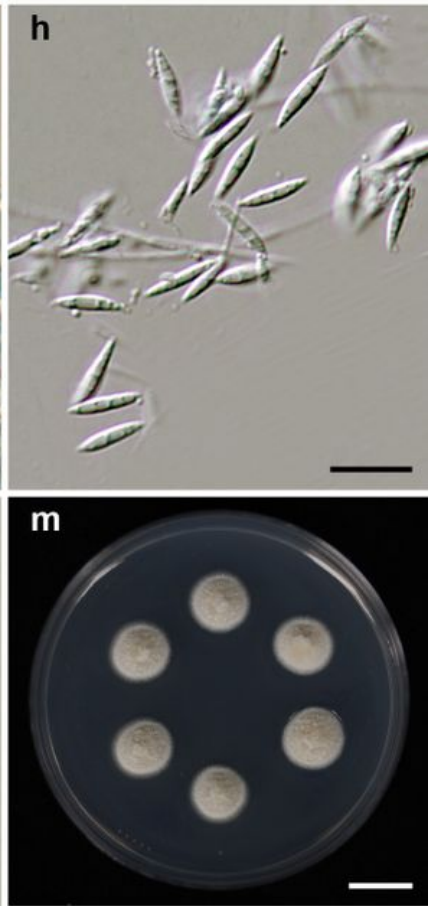

n

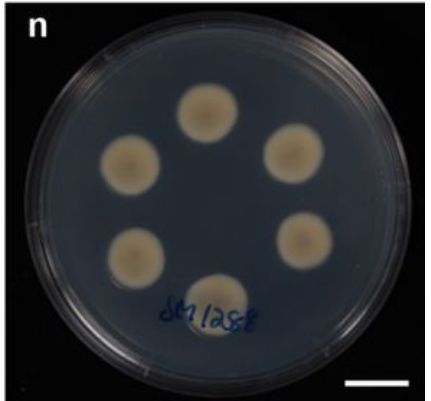

\section{Figure 6}

Moelleriella nivea. a, b Anamorphic stroma containing conidiomata. c, d Telemorphic stroma. e-f Section of stroma showing conidioma. g Phialide with conidia at the tips. h conidia. i Perithecia. j Mature asci with developing asci. $\mathrm{k}$ Asci and caps. I Part-spores. $\mathrm{m}$ Colony obverse on PDA at $25^{\circ} \mathrm{C}$ after $1 \mathrm{wk}$. $\mathrm{n}$ Colony reverse on PDA at $25^{\circ} \mathrm{C}$ after $1 \mathrm{wk}$. Scale bars: $\mathrm{m}, \mathrm{n}=10 \mathrm{~mm}$. a-d = $1 \mathrm{~mm} . \mathrm{e}, \mathrm{i}=200 \mu \mathrm{m} . \mathrm{f}=100 \mu \mathrm{m} . \mathrm{j}=20 \mu \mathrm{m} . \mathrm{g}, \mathrm{h}, \mathrm{k}, \mathrm{I}=10 \mu \mathrm{m}$. 

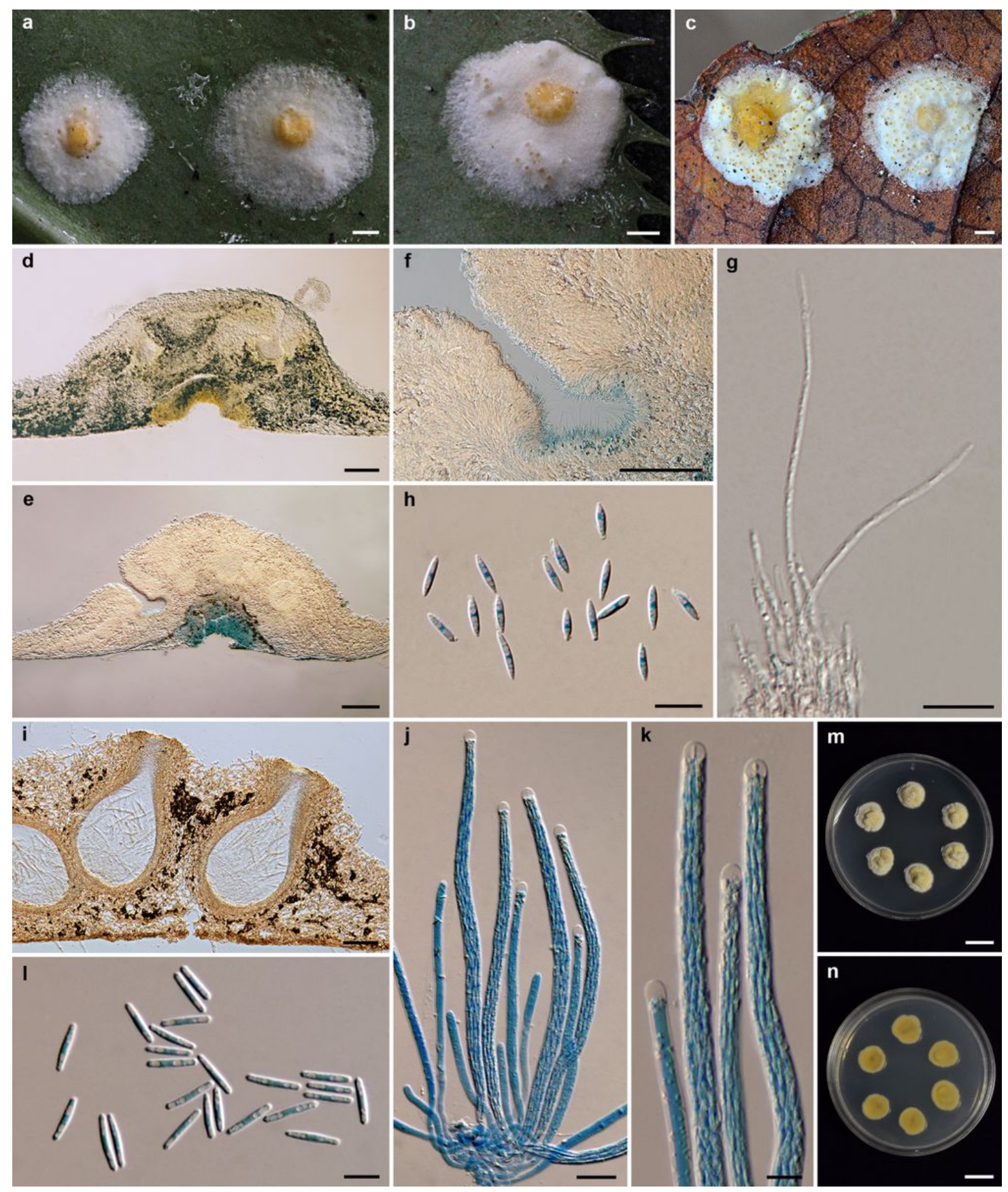

Figure 7

Moelleriella sinensis. a Anamorphic stromata. b, c Anamorphic and telemorphic stromata containing conidiomata. $d$-f Section of stroma showing conidioma. g Phialide and conidium at the tips with papaphyses. h conidia. i Perithecia. j Mature asci with developing asci. k Asci and caps. I Part-spores. $\mathrm{m}$ Colony obverse on PDA at $25^{\circ} \mathrm{C}$ after 2 wk. $\mathrm{n}$ Colony reverse on PDA at $25^{\circ} \mathrm{C}$ after 2 wk. Scale bars: $\mathrm{m}, \mathrm{n}=10 \mathrm{~mm}$. $a-c=1 \mathrm{~mm}$. d, e = $200 \mu \mathrm{m} . \mathrm{f}, \mathrm{i}=100 \mu \mathrm{m} . \mathrm{j}=20 \mu \mathrm{m} . \mathrm{g}, \mathrm{h}, \mathrm{k}, \mathrm{I}=$ $10 \mu \mathrm{m}$. 